
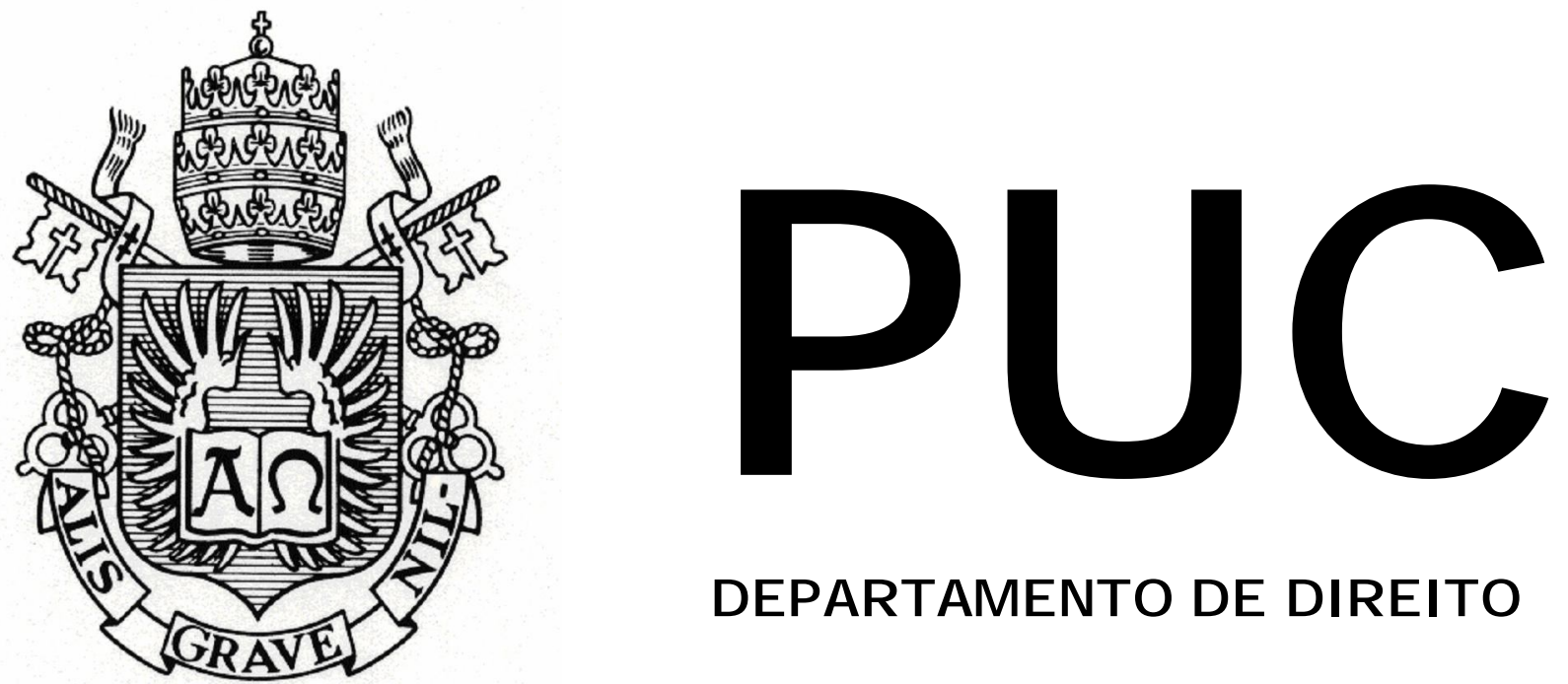

DEPARTAMENTO DE DIREITO

\title{
AS TÉCNICAS DE REPRODUÇÃO HUMANA ASSISTIDA E AS SUAS IMPLICAÇÕES NA ESFERA DA RESPONSABILIDADE CIVIL
}

por

GISELLE CRISTINA ALVES GIMENES

ORIENTADOR: KÁTIA REGINA DA COSTA SILVA 2009.1

PONTIFÍCIA UNIVERSIDADE CATÓLICA DO RIO DE JANEIRO RUA MARQUÊS DE SÃO VICENTE, 225 - CEP 22453-900 RIO DE JANEIRO - BRASIL 


\section{AS TÉCNICAS DE REPRODUÇÃO HUMANA ASSISTIDA E AS SUAS IMPLICAÇÕES NA ESFERA DA RESPONSABILIDADE CIVIL}

por

GISELLE CRISTINA ALVES GIMENES

Monografia apresentada ao Departamento de Direito da Pontifícia Universidade Católica do Rio de Janeiro (PUC-Rio) como requisito parcial para a obtenção do Título de Bacharel em Direito.

Orientador(a): Kátia Regina da Costa Silva 
Aos meus pais José Mário e Maria Cristina.

À querida Vovó Amélia.

Aos meus irmãos Joyce e Daniel.

Ao meu namorado Ian Borges. 


\section{AGRADECIMENTOS}

Agradeço a Deus, por conceder a vida e tudo o que nela há.

Aos meus pais, José Mário e Maria Cristina, essenciais na minha formação, pelo amor, educação e incentivo de sempre.

À Vovó Amélia pelas suas histórias e atenção.

Aos meus irmãos Joyce e Daniel por todo o apoio e amizade.

Ao meu namorado Ian pelo seu estímulo, amor e companheirismo.

Agradeço à professora orientadora Kátia Regina da Costa Silva e à professora e co-orientadora, Caitlin Sampaio, pelas experiências e conhecimentos que contribuíram de modo singular à produção desta monografia.

Aos meus colegas e professores da PUC - Rio.

Aos funcionários do departamento.

A todos os amigos e familiares que de uma forma ou de outra me estimularam e me ajudaram. 


\section{RESUMO}

O presente trabalho visa abordar o recente e polêmico tema da Reprodução Humana Assistida sob o enfoque da Responsabilidade Civil. No atual contexto de transformação nas famílias, faz-se necessário um diálogo entre as inovações científicas e a adequação jurídica dos comportamentos delas advindos. Ganha relevo, portanto, a reflexão do cabimento da responsabilidade civil neste locus. Cabe ao Direito dispor de mecanismos assecuratórios eficientes às relações contratuais e extracontratuais firmadas entre as partes envolvidas nesse procedimento e a proteção da vida das futuras gerações.

\section{PALAVRAS-CHAVE}

Reprodução Humana Assistida, Responsabilidade Civil, Biodireito, Bioética, Filiação e Princípios Constitucionais. 


\section{SUMÁRIO}

INTRODUÇÃO

\section{CAPÍTULO I: BIODIREITO: SURGIMENTO DE UM NOVO RAMO JURÍDICO E PRINCÍPIOS QUE O ORIENTAM}

1.1 - Histórico e Princípios da Bioética ............................................................... 11

1.2 - Princípios Constitucionais ....................................................................... 17

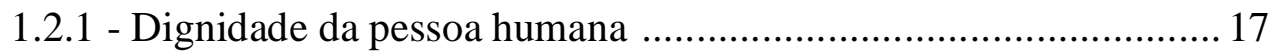

1.2.2 - Direito à vida e à existência ………………………………...... 19

1.2.3 - Direito ao planejamento familiar .............................................. 21

1.2.4 - O conflito entre princípios fundamentais …………………....... 23

\section{CAPÍTULO II - AS TÉCNICAS DE REPRODUÇÃO HUMANA} ASSISTIDA (RHA)

2.1 - Considerações Iniciais ..........................................................................25

2.2 - A Evolução Histórica ......................................................................................27

2.3 - As Técnicas de Reprodução Humana Assistida ...................................... 28

2.3.1 - Inseminação artificial ............................................................ 28

2.3.2 - Transferência Intratubária de Gametas (GIFT) ……………….... 29

2.3.3 - Fertilização in vitro (FIVETE) ……………................................. 29

2.3.4 - Maternidade de Substituição ....................................................... 30

2.4 - Aspectos Jurídicos da Reprodução Humana Assistida .......................... 31 


\section{CAPÍTULO III - A RESPONSABILIDADE CIVIL}

3.1 - Noções Gerais .................................................................................................... 34

3.2 - A Responsabilidade Subjetiva e Responsabilidade Objetiva ..............37

3.3 - A Responsabilidade Profissional do Médico .......................................... 43

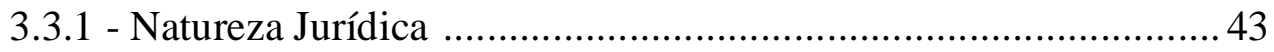

3.3.2 - A relação com o Código de Defesa do Consumidor .................... 45

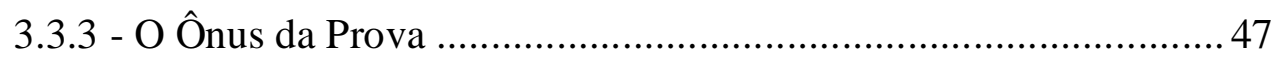

\section{CAPÍTULO IV - A RESPONSABILIDADE CIVIL NA REPRODUÇÃO HUMANA ASSISTIDA}

4.1 - O consentimento livre e esclarecido .........................................................50

4.2 - O sigilo profissional .....................................................................52

4.3 - A Responsabilidade Civil das Clínicas de Reprodução Assistida e dos Bancos de Depósito de Material Fertilizante ....................................................55

4.4 - A Responsabilidade Civil perante os doadores e receptores ...............59

4.5 - Existe Responsabilidade Civil por dano ao embrião in vitro? .............61

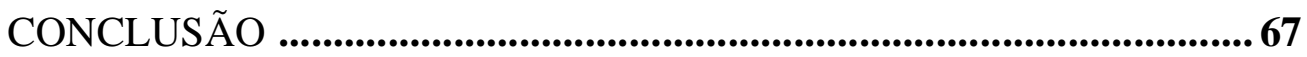

BIBLIOGRAFIA …............................................................................................ 71

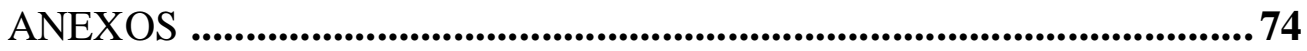




\section{INTRODUÇÃO}

O problema da esterilidade fez com que inúmeras pesquisas e avanços científicos fossem desenvolvidos. Contudo, esse grande desenvolvimento tecnológico no campo da Reprodução Humana Assistida trouxe consigo reflexões e discussões sobre a importância de haver normas jurídicas que orientassem estas questões.

Podemos perceber que ainda falta uma legislação específica para disciplinar estas condutas. Neste sentido, leciona Paulo Nader sobre a área da atuação médica.

"Dado o grande volume de casos levados aos tribunais e a consequiente formação jurisprudencial, além da crescente produção doutrinária, o legislador dispõe de elementos para editar um estatuto de responsabilidade civil destinado às atividades na área da saúde. Há especialidades novas, como a da reprodução assistida, que ainda carecem de firmeza de orientação no campo da responsabilidade civil." 1

Sem embargo, apesar desta carência, não há como frear o avanço tecnológico e a utilização destas técnicas de reprodução artificial. Cada vez mais nossos tribunais hão de se deparar com questões atinentes à responsabilidade civil em razão de usuários que, ao se sentirem lesados por ato do corpo médico, recorrerão ao Judiciário para ver ressarcido seu dano.

Assim, torna-se necessário regular esta atividade e solucionar os casos concretos. Enquanto não houver previsão legal, cabe aos acadêmicos de Direito vislumbrarem possíveis soluções.

\footnotetext{
${ }^{1}$ NADER, Paulo. Curso de Direito Civil. $1^{\text {a }}$ ed. Rio de Janeiro: Forense, 2008. p.386
} 
Estabelece o art. $4^{\circ}$ da Lei de Introdução ao Código Civil que quando a lei for omissa, o juiz decidirá o caso de acordo com a analogia, os costumes e os princípios gerais de direito. Da mesma forma, o art. 126 do Código de Processo Civil determina que o Juiz não se exime de sentenciar ou despachar, mesmo na hipótese de lacuna ou obscuridade da lei, e $o$ julgamento da lide recorrerá à analogia, aos costumes e aos princípios gerais de direito.

Coube a Rudolph Von Jhering, segundo Tânia da Silva Pereira, "demonstrar que as regras jurídicas e as soluções que consagram são essencialmente pelo fim prático e pelo fim social das instituições". ${ }^{2}$

Desta forma, em razão do fim prático devemos observar os Princípios Gerais de Direito, bem como os Princípios da Bioética, que atuam como indicadores de uma opção pelo favorecimento de um determinado valor. ${ }^{3}$

Isto ocorre, pois podemos nos deparar com situações que geram questionamentos sobre como agir no mundo dos fatos. Por exemplo, teria o nascido da doação de gametas o direito de conhecer seus pais biológicos? $\mathrm{E}$ nesse caso, haveria alguma relação civil com sua família biológica? Teria direito à herança? Haveria algum direito civil do pré-embrião congelado em laboratório, como se nascituro fosse?

Essas questões e muitas outras permanecem sem resposta. Este trabalho não visa solucionar a todas elas, mas se debruça sobre um tema que é essencial para a construção de uma solução jurídica adequada: a responsabilização daqueles que realizam as técnicas de Reprodução

\footnotetext{
${ }^{2}$ PEREIRA, Tânia da Silva. O melhor interesse da criança: um debate interdisciplinar. Rio de Janeiro/São Paulo: Renovar, 2000. p.23

${ }^{3}$ Ibid. p.25.
} 
Assistida e a garantia de que a pessoa nascida das referidas técnicas tenha seus direitos e a dignidade da pessoa humana respeitados.

Apesar de todos os casos estudados envolverem questões muito delicadas e sentimentos profundos, o objetivo deste trabalho não é analisar questões religiosas, éticas, de comportamento ou psicológicas, mas sim focar no ponto de vista jurídico.

O mundo científico evoluiu de tão maneira que o direito não conseguiu acompanhar e nossa intenção é, desta forma, trazer à tona esses questionamentos e dúvidas, na busca de um caminho que possa levar a algumas soluções condizentes com os dias atuais.

Diante de todo o exposto, surge uma pergunta chave: a reprodução assistida serve à dignidade do homem ou conspira para a desumanização? $\mathrm{O}$ que esta em jogo é a vida humana cujo valor e dignidade não podem ser ignorados por ninguém. ${ }^{4}$ Vale a pena refletirmos com algumas palavras do filósofo Schopenhauer:

"Queixamo-nos de que vivemos na ignorância, incapazes de entender a relação entre todos os fatos da existência, e em particular, a relação entre nossa existência particular e o todo da existência. Não apenas a vida é curta, mas nosso conhecimento dela é drasticamente limitado." 5

Para chegarmos a uma resposta, trilhamos o caminho do Biodireito, um novo ramo da ciência jurídica que deve pautar-se nos princípios da Bioética e nos princípios constitucionais, até alcançarmos o objetivo primordial que é a situação jurídica do relacionamento médico-paciente na atual conjuntura.

\footnotetext{
${ }^{4}$ BOLZAN, Alejandro D. Reprodução Humana Assistida e dignidade humana. São Paulo: Paulinas, 1998, p.7

${ }^{5}$ SCHOPENHAUER, Arthur. Sobre a coisa em si e a aparência In: Strathern, Paul. Schopenhauer em 90 minutos.
} 
Ao longo do trabalho, serão discutidos alguns tópicos que ajudam a explicar o surgimento das novas técnicas de reprodução humana, e os fatores que podem facilitar o desenvolvimento de uma prática responsável e consciente. Serão enfatizados alguns aspectos do Direito de Família que tiveram grande impacto no que diz respeito à filiação e presunção de paternidade.

Exaustiva pesquisa de jurisprudência será realizada com a finalidade única de identificar o posicionamento de nossos Tribunais sobre a responsabilidade dos médicos e das Clínicas. É perfeitamente normal a constatação de que o número de processos de responsabilidade siga uma curva de crescimento paralela à do progresso científico e à do aumento das curas que ele produz.

O objetivo principal deste trabalho é trazer em linhas gerais algumas questões relevantes de interesse para pacientes, médicos e operadores de Direito. Esperamos mesmo com a singeleza da presente dissertação, dar uma contribuição, por mínima que seja, ao estudo da Responsabilidade Civil, a fim de possibilitar uma melhor atuação jurisdicional nas demandas que envolvam as técnicas de reprodução humana assistida. 


\section{CAPÍTULO I}

\section{BIODIREITO: SURGIMENTO DE UM NOVO RAMO JURÍDICO E PRINCÍPIOS QUE O ORIENTAM.}

\subsection{HISTÓRICO E PRINCÍPIOS DA BIOÉTICA}

A temática que desafia a reflexão filosófica e jurídica no século XXI relaciona-se com a questão da vida humana. Trata-se de saber até que ponto as ciências da vida, especificamente as tecnologias, alteram a natureza da vida humana e seus reflexos na sociedade.

O século que ora finda foi marcado principalmente por três mega projetos. Primeiro foi o projeto Manhatan, que descobriu e utilizou a energia nuclear bem como produziu a bomba atômica que destruiu Hiroshima e Nagasaki(1945), pondo fim à II Guerra Mundial. O segundo grande marco foi o projeto Apollo cuja data símbolo é o primeiro passo do homem na Lua (1969) e que jogou o ser humano no coração do cosmos. O terceiro e mais recente é o Projeto Genoma Humano que teve começo no início dos anos 90. Esta última descoberta leva o ser humano ao mais profundo de si mesmo em nível de conhecimento de sua herança biológica, numa incessante busca de respostas através dos genes. ${ }^{6}$

Olhando retrospectivamente, é possível observar como herança, não apenas transtornos e destruições causados por guerras mundiais, mas o triunfo da revolução biotecnológica e da fissão nuclear, a possibilidade de transformação do patrimônio genético, e o crescente poder tecnológico sobre o corpo e a mente. Neste contexto, se faz necessário impor limites à

\footnotetext{
${ }^{6}$ PESSINI, Leo. Fundamentos da BIOÉTICA. São Paulo, 3 a ed. São Paulo: Paulus, 2005. p.5
} 
atuação humana, num ambiente de diálogo livre e respeitoso, em sadia qualidade de vida e dignidade da pessoa humana através das pautas indicadas pela bioética e pelo biodireito. ${ }^{7}$

De acordo com a Encyclopedia of bioethics Bioética é um neologismo derivado das palavras gregas bios(vida) e ethike( ética). Podese defini-la como o estudo sistemático das dimensões morais-incluindo visão, decisão, conduta e normas morais - das ciências da vida e da saúde, utilizando uma variedade de metodologias éticas num contexto interdisciplinar. $^{8}$

É importante mencionar a origem e evolução cronológica da bioética. O primeiro documento considerado como marco inicial foi o Código de Nuremberg, elaborado em 1947, logo após a Segunda Guerra Mundial, em decorrência das atrocidades praticadas pelos médicos nazistas em experiências com os seres humanos.

Em seguida, o Relatório Belmont foi oficialmente promulgado em 1978. Tornou-se a declaração principialista clássica, não somente para a ética da experimentação humana, mas para a reflexão ética em geral. Por meio desse relatório foi possível identificar a proposta da comissão: articular três princípios éticos, supostamente universais, que promoveriam as bases conceituais para a formulação, a crítica e a interpretação de dilemas morais envolvendo a pesquisa científica. ${ }^{9}$

Em 1982, o Conselho da Europa elaborou a Recomendação nº 934, que dispôs sobre os limites à atividade de engenharia genética,

\footnotetext{
${ }^{7}$ DINIZ, Maria Helena. O Estado Atual do biodireito. $2^{\text {a }}$ ed. São Paulo: Saraiva, 2002. p.1

${ }^{8}$ Encyclopedia of bioethics. Aput: PESSINI, Leo. Problemas atuais de Bioética. $6{ }^{a}$ edição. São Paulo, 2002. p.32

${ }^{9}$ DINIZ, Debora ; Guilhem, Dirce. O que é Bioética. São Paulo:brasiliense, 2002. p.22
} 
estabelecendo que cada país deve exercer um efetivo controle público sobre as pesquisas genéticas, principalmente no tocante à manipulação de genes.

Em 1995, o Brasil promulgou a Lei de Biossegurança ( Lei $n^{\circ}$ 8.974/95), regulamentando os incisos II e V do parágrafo $1^{\circ}$ do artigo 225 da Constituição Federal, estabelecendo normas para o uso das técnicas de engenharia genética e liberação no meio ambiente de organismos geneticamente modificados(OGM) e autorizando o Poder Público a criar a Comissão Técnica Nacional de Biossegurança (CTNBio).

Ainda em 1996, no Brasil, o Conselho Nacional de Saúde, órgão do Ministério da Saúde, elaborou a Resolução n¹96/96, estabelecendo níveis de risco e fornecendo orientações normativas para a boa conduta ética e de segurança a serem observadas nas pesquisas de saúde envolvendo seres humanos.

Em 1997 a Declaração Universal do Genoma Humano e dos Direitos Humanos demonstrou claramente a preocupação dos cientistas de todo o mundo em proteger o homem da exploração comercial. ${ }^{10}$

As principais características da bioética segundo Leo Pessini são:

"ser uma ciência da qual o homem é sujeito e não somente objeto; ter como critérios: a beneficência, a autonomia e a justiça - a chamada "trindade bioética" _ cuja articulação assenta-se no tripé, nem sempre harmonioso: médico (pela beneficência), paciente (pela autonomia) e a sociedade (pela justiça)". ${ }^{11}$

O princípio da autonomia estabelece que, cada ser humano tem direito de escolha e decisão sobre sua própria vida, bem como sobre as atividades que impliquem alterações em sua condição de saúde física ou mental. Assim, requer que o profissional da saúde respeite a vontade do

\footnotetext{
${ }^{10}$ FERNANDES, Silvia da Cunha. As Técnicas de Reprodução Humana Assistida e a Necessidade de sua Regulamentação Jurídica.Rio de Janeiro:Renovar, 2005. p.10-12

${ }^{11}$ PESSINI, Leo. Fundamentos da BIOÉTICA. $3^{\mathrm{a}}$ ed. São Paulo: Paulus, 2005, p.5
} 
paciente, ou de seu representante, em razão de seus valores morais e crenças religiosas.

Desse princípio decorre a exigência do consentimento livre e informado e a maneira de como tomar decisões de substituição quando uma pessoa for incompetente ou incapaz.

O princípio da beneficência requer o atendimento por parte do médico ou do geneticista aos mais importantes interesses das pessoas envolvidas nas práticas biomédicas ou médicas. Neste sentido são formuladas duas regras como expressões complementares dos atos de beneficência: maximizar os benefícios e minimizar os possíveis riscos e não causar dano. $^{12}$

O princípio da justiça é entendido como a imparcialidade na distribuição dos riscos e benefícios, no que atina à prática médica pelos profissionais da saúde, pois os iguais deverão ser tratados igualmente.

O princípio da não-maleficência é um desdobramento do da beneficência, por conter a obrigação de não acarretar dano intencional e por derivar da máxima da ética médica: primium nom nocere ${ }^{13}$. Tal princípio, encontra-se intimamente ligado ao juramento de Hipócrates, o qual afirma: "aplicarei os regimes para o bem dos doentes, segundo o meu saber e a minha razão, e nunca para prejudicar ou fazer o mal a quem quer que seja".

Desta forma, a Bioética deve pautar-se num conjunto de pesquisas e práticas multidisciplinares, para que possa ir ao encontro de respostas para as indagações formuladas em face dos avanços das ciências e tecnologias.

\footnotetext{
${ }^{12}$ PESSINI, Leo; BARCHIFONTAINE, Christian. Problemas atuais de Bioética. $6^{\text {a }}$ ed. São Paulo: Loyola, 2002. p.46.

${ }^{13}$ DINIZ, Maria Helena. O Estado Atual do biodireito. $2^{\text {a }}$ ed. São Paulo: Saraiva, 2002 p.
} 
Nesse contexto, surge o Biodireto, novo ramo da ciência jurídica, que tem por objeto a análise, a partir de seus princípios, normas e metodologias, das múltiplas relações que encontram-se vinculadas ao início da vida, ao seu transcurso e ao seu fim. ${ }^{14}$

O Biodireito é o conjunto de regras jurídicas já positivadas que visam estabelecer a obrigatoriedade de observância dos mandamentos bioéticos, voltados a impor ou proibir uma conduta médico-científica, e, ao mesmo tempo, é a discussão sobre a adequação - necessidade de ampliação ou restrição- desta legislação.

Para Francisco Amaral, o Biodireito nada mais é do que um fértil processo de mudanças jurídicas, impostas pelos problemas da sociedade tecnológica, que tornou extremamente complexo o relacionamento social e impôs crescentes desafios às estruturas herdadas do século XIX. A resposta a esses desafios exige dos juristas e, particularmente, dos atuais civilistas, um esforço de reflexão profunda que lhes permita, a partir do conhecimento do direito brasileiro na sua origem e evolução, elaborar novos modelos que atendam às necessidades crescentes da sociedade contemporânea. ${ }^{15}$

Conforme elucida o mestre Caio Mário da Silva Pereira, a ciência biológica tem estreita relação com o mundo jurídico:

"Quando a ciência biológica anuncia processo de inseminação artificial, para proporcionar a gestação sem o pressuposto fisiológico das relações sexuais, uma série de implicações jurídicas eclode, como seja a indagação da legitimidade do filho, a necessidade de autorização da mulher, a anuência do marido, o registro do filho, afora o problema da inseminação contra a vontade de qualquer dos cônjuges, ou a sua realização sem o conhecimento do fato por algum deles, ou a necessidade de reconhecimento ou declaração da paternidade.

Estudos recentes na Doutrina Brasileira enfrentam com coragem aspectos jurídicos relevantes relativos ao tema. A ausência de uma regulamentação legal impõe o desafio ao jurista de participar das avaliações científicas indicando os

\footnotetext{
${ }^{14}$ PÁDUA, Amélia do Rosário Motta de. Responsabilidade Civil na reprodução Assistida. Rio de Janeiro: Lumen Juris, 2008. p.49

${ }^{15}$ AMARAL, Francisco. A visão do Biodireito. In: Anais do Encontro Regional do Simpósio de Bioética e Biodireito. 1997, p.12
} 
elementos ético-jurídicos que deverão orientar a pesquisa. Não deve ser ele, apenas, um mero elaborador de normas proibitivas.". ${ }^{16}$

Na visão de Caio Mário, se de um lado as técnicas de reprodução humana assistida confrontam os conceitos de início da vida e da sua proteção jurídica, de outro os transplantes de órgãos e tecidos e a possibilidade de prolongamento da vida colocaram em cheque o conceito morte.

Será preciso buscar um ponto de equilíbrio entre duas posições antitéticas: proibição total de qualquer atividade biomédica, que traria uma radical freada no processo científico, ou permissividade plena, que geraria insanáveis prejuízos ao ser humano e à humanidade.

O surgimento dessas situações faz com que o biodireito, pouco a pouco, se afirme, reunindo doutrina, legislação e jurisprudência próprias, regulando a conduta humana tendo em vista os avanços da biotecnologia e da biomedicina.

Cabe ao direito, por meio da lei, definir a ordem social, na medida em que dispõe dos meios próprios e adequados para que essa ordem seja respeitada. Contudo, em alguns casos essa significação é dificultada porque certos princípios estruturais do direito são fundados na representação implícita do destino biológico do homem como a indisponibilidade do corpo ou a fronteira entre as pessoas e as coisas, o que não é mais fundamentalmente ajustável como o novo domínio do homem sobre os seres humanos. ${ }^{17}$

\footnotetext{
${ }^{16}$ PEREIRA,Caio Mário da Silva. Instituições de Direito Civil. Vol. V. $16^{\mathrm{a}}$ ed. Rio de Janeiro: Forense, 2006. pág.9

${ }^{17}$ Ibid.
} 
Considerando que a maioria dos fatos a serem regulamentados pelo biodireito é inédita, ou seja, não cogitados pelo ordenamento em sua formulação original, torna-se necessária a constante observância dos princípios vigentes, preservando-se os valores escolhidos pela sociedade.

Os princípios constitucionais compreendem os valores primordiais de nossa sociedade, demonstrando, em sua maioria, direitos fundamentais do homem como o direito à vida e à existência. Por sua natureza os princípios constitucionais devem constituir os princípios do biodireito. Em conseqüência, não poderão as regras de biodireito preterir esses princípios.

\subsection{PRINCÍPIOS CONTITUCIONAIS}

\subsubsection{PRINCÍPIO DA DIGNIDADE DA PESSOA HUMANA}

Em se tratando de reprodução humana assistida, não podemos perder de vista um dos princípios básicos do direito: o da dignidade da pessoa humana, consagrado no texto da Constituição Federal, em seu art. $1^{\circ}$, III, o qual sempre deverá servir de base para a utilização de qualquer das técnicas de reprodução artificial.

$\mathrm{O}$ respeito à dignidade da pessoa humana tornou-se um comando jurídico no Brasil com o advento da Constituição Federal de 1988. Após mais de duas décadas de ditadura sob o regime militar, a Constituição explicitou a dignidade da pessoa humana como um dos "fundamentos da República". Isto significa dizer que o valor da dignidade alcança todos os setores da ordem jurídica. ${ }^{18}$

\footnotetext{
${ }^{18}$ MORAES, Maria Celina Bodin de. Danos à Pessoa Humana: uma leitura civil-constitucional dos danos morais. Rio de Janeiro: Renovar, 2003. p. 82 - 128.
} 
O fundamento material da dignidade pode ser desdobrado em quatro postulados: o sujeito moral reconhece a existência dos outros como sujeitos iguais a ele; merecedores do mesmo respeito à integridade psicofísica de que é titular; é dotado de vontade livre; e é parte do grupo social. E são base da dignidade os princípios da igualdade, da integridade psicofísica, da liberdade e da solidariedade. ${ }^{19}$

O fundamento jurídico da dignidade humana manifesta-se no princípio da igualdade, isto é, no direito de não receber tratamento discriminatório, no direito de ter direitos iguais aos de todos os demais, conhecida como "igualdade formal". Existe também a igualdade substancial, cuja medida prevê a necessidade de tratar as pessoas, quando desiguais em conformidade com sua desigualdade.

$\mathrm{Na}$ tutela da integridade psicofísica estão tradicionalmente protegidos o direito de não ser torturado e o de ser titular de certas garantias penais. No entanto, na esfera cível, a integridade psicofísica vem servindo a garantir numerosos direitos da personalidade, instituindo hoje o que se poderia entender como um amplíssimo "direito à saúde", compreendida esta como bem-estar psicofísico e social. ${ }^{20}$

Atualmente, as maiores perplexidades em torno do tema dizem respeito ao extraordinário desenvolvimento da biotecnologia e às suas conseqüências sobre a esfera psicofísica do ser humano.

O princípio da liberdade individual se consubstancia, cada vez mais, numa perspectiva de privacidade, de intimidade, de exercício da vida privada. Liberdade significa hoje poder realizar, sem interferências de

\footnotetext{
${ }^{19}$ Ibid.

${ }^{20}$ Definição dada pela OMS - Organização Mundial de Saúde
} 
qualquer gênero, as próprias escolhas individuais, exercendo-as como melhor convier.

Ao direito de liberdade da pessoa, porém, será contraposto o dever de solidariedade social, identificado como um conjunto de instrumentos voltados para garantir uma existência digna, comum a todos, em uma sociedade que se desenvolva como livre e justa, sem excluídos ou marginalizados.

Segundo Guilherme Nogueira da Gama:

"A dignidade é, portanto, um valor próprio e extrapatrimonial da pessoa humana, especialmente no contexto do convívio na comunidade, como sujeito moral. Não há dúvida que todos os interesses têm como centro a pessoa humana, a qual é o foco principal de qualquer política pública ou pensamento, sendo imperioso harmonizar a dignidade da pessoa humana ao progresso científico e tecnológico, porquanto este deve tender sempre a aprimorar e melhorar as condições e a qualidade de vida das pessoas humanas, e não o inverso." ${ }^{21}$

Com base no pensamento de Immanuel Kant, nos termos do princípio da dignidade da pessoa humana, a pessoa nunca deve ser pensada como instrumento (ou meio), mas sempre como um fim. ${ }^{22}$

\subsubsection{DIREITO À VIDA E À EXISTÊNCIA}

O direito à vida é o mais fundamental da todos os direitos, já que se constitui em pré-requisito à existência e exercício de todos os demais direitos. $^{23}$

\footnotetext{
${ }^{21}$ GAMA, Guilherme Nogueira da. A nova Filiação: o biodireito e as relações parentais. Rio de Janeiro/ São Paulo: 2003. p.131.

${ }^{22}$ Ibid.

${ }^{23}$ DE MORAIS, Alexandre. Direito Constitucional. $15^{\mathrm{a}}$ ed. São Paulo: Atlas, 2004. p.65
} 
É notória a relação entre o princípio da dignidade da pessoa humana e o direito à vida, considerando logicamente que para que haja dignidade reconhecida concretamente deve ser constatada a vida que, por sua vez, merece ser construída e desenvolvida com respeito, garantia e promoção da dignidade da pessoa. ${ }^{24}$

José Afonso da Silva, na tentativa de definir o que se chama vida, afirma que sua riqueza significativa é de difícil apreensão porque é algo dinâmico:

"É mais um processo (processo vital), que se instaura com a concepção (ou germinação vegetal), transforma-se, progride, mantendo sua identidade, até que muda de qualidade, deixando, então, de ser vida para ser morte. Tudo que interfere em prejuízo deste fluir espontâneo e incessante contraria a vida." ${ }^{25}$

A tutela da vida humana tem início na concepção nos termos do art. $2^{\circ}$ do Código Civil, já que o nascituro, independentemente da análise do início da personalidade jurídica, é um ser humano, merecedor de toda proteção que se lhe possa conferir. $\mathrm{O}$ aborto é previsto como crime nos arts. 124 a 128 do Código Penal.

A Constituição Federal proclama, portanto, o direito à vida, cabendo ao Estado assegurá-lo em sua dupla acepção, sendo a primeira relacionada ao direito de continuar vivo e a segunda de se ter vida digna quanto à subsistência. ${ }^{26}$

O direito à existência, por sua vez, é o direito de não ter interrompido o processo vital senão pela morte espontânea e inevitável. A vida humana é bem indisponível, nem o seu titular pode dela dispor.

\footnotetext{
${ }^{24}$ Ibid.

${ }^{25}$ DA SILVA, José Afonso. Curso de Direito Constitucional Positivo. 24a ed. Malheiros Editores, 2005. p. 197

${ }^{26}$ Acórdão do Egrégio Tribunal de Justiça, relatado pelo Desembargardor Renan Lotufo, in Cadernos de Direito Constitucional e Ciência Política
} 
Existir é o movimento espontâneo contrário ao estado de morte. Nas palavras de José Afonso da Silva: "Consiste no direito de estar vivo, de lutar pelo viver, de defender a própria vida, de permanecer vivo" ${ }^{27}$ Porque se assegura o direito à vida, é que a legislação penal pune todas as formas de interrupção violenta do processo vital, incluindo o aborto e a eutanásia.

\subsubsection{DIREITO AO PLANEJAMENTO FAMILIAR}

A Carta Magna dispõe, no art. $226 \S 7^{\circ}$, que o planejamento familiar é livre decisão do casal, fundado nos princípios da dignidade da pessoa humana e da paternidade responsável.

A paternidade responsável representa a assunção de deveres parentais em decorrência dos resultados do exercício dos direitos reprodutivos, mediante conjunção carnal ou com recurso a alguma técnica reprodutiva. ${ }^{28}$

Assim, o planejamento familiar, singelamente referido no código civil artigo $1.565 \$ 2^{\circ}$, é um direito fundamental, e ao mesmo tempo constitui responsabilidades no campo das relações de parentalidade-filiação. Essa responsabilidade se mostra vitalícia, vincula a pessoa a situações jurídicas existenciais e patrimoniais relacionadas ao seu filho, à sua descendência.

\footnotetext{
${ }^{27}$ DA SILVA, José Afonso. Curso de Direito Constitucional Positivo. 24 $4^{\mathrm{a}}$ ed. Malheiros Editores, 2005. p. 198.

${ }^{28}$ GAMA, Guilherme Nogueira da. A nova Filiação: o biodireito e as relações parentais. Rio de Janeiro, São Paulo. 2003. p.453
} 
Se o casal reputa fundamental para a sua felicidade e harmonia familiar a constituição de prole, não há como negar a possibilidade do recurso às técnicas reprodutivas. ${ }^{29}$ Assim, é dever do Estado, garantir aquelas pessoas pobres na acepção jurídica do termo o planejamento familiar nos termos da Lei no 9.263/1996 (Planejamento Familiar), bem como acesso às técnicas de reprodução humana assistida às pessoas carentes que não tem condições de ter filho pelo procedimento natural de reprodução.

Neste sentido, a Portaria $n^{\circ} 426^{30}$ de 22 de março de 2005 do Ministério da Saúde, institui a Política Nacional de Atenção Integral em Reprodução Humana Assistida no âmbito do SUS previsto na Constituição Federal de 1988 (Título VIII, capítulo II, seção II) e nas Leis 8.080/90 e $8.142 / 90$.

Observa-se, portanto, que há no Brasil previsão legal para que o Estado proporcione aos cidadãos o acesso aos recursos científicos necessários e disponíveis a atender o direito de gerar filhos. Diante desse fato, alguns hospitais públicos passaram a oferecer serviços gratuitos de reprodução assistida, porém com capacidade limitada de atendimento, insuficiente para atender a demanda.

Desta forma, muitas mulheres sem condições de arcar com as despesas de tratamento em clínicas particulares de infertilidade estão longe de se beneficiar das técnicas modernas de reprodução assistida, tendo em vista as longas filas de espera nos centros públicos que dispõem do serviço, como já observado, evidenciando que o princípio da igualdade na saúde pública brasileira não está atingindo aqueles que precisam ser vistos na sua individualidade.

\footnotetext{
${ }^{29}$ Ibid.

${ }^{30}$ A íntegra desta Portaria encontra-se no anexo I desta obra.
} 


\subsubsection{O CONFLITO ENTRE DIREITOS FUNDAMENTAIS}

É possível ocorrer colisão de princípios no momento da aplicação no caso concreto. Os conflitos de direitos fundamentais são espécies de antinomias normativas para Jane Reis Gonçalves Pereira que assim as define:

"As antinomias são contradições entre normas que ocorrem quando estas atribuem conseqüências divergentes para uma mesma situação de fato, ou seja, quando, diante de um mesmo suposto fático, encontramos no ordenamento comandos em sentidos opostos que não podem ser efetivados ao mesmo tempo.",31

Em geral, os conflitos de direito fundamental, só podem ser identificados no momento aplicativo, já que as normas que os consagram revelam-se compatíveis em abstrato.

Essa noção pode ser ilustrada com alguns exemplos. A utilização de novas técnicas de reprodução dá origem ao polêmico conflito entre o direito à identidade genética que é um direito da personalidade e o direito ao anonimato do doador de material genético.

Havendo conflito entre livre expressão da atividade científica e outro direito fundamental da pessoa humana, a solução ou o ponto de equilíbrio deverá ser o respeito à dignidade humana, fundamento do Estado Democrático de Direito, previsto no art. $1^{\circ}$, III, da Constituição Federal. ${ }^{32}$

Neste sentido leciona Maria Helena Diniz:

“A Constituição Federal de 1988, em seu art. 5º IX, proclama a liberdade da atividade científica como um dos direitos fundamentais, mas isso não significa que ela seja absoluta e não contenha qualquer limitação, pois há outros valores e bens jurídicos reconhecidos constitucionalmente, como a vida, a integridade

\footnotetext{
${ }^{31}$ PEREIRA, Jane Reis Gonçalves. Interpretação Constitucional e Direitos

Fundamentais. São Paulo: Renovar, 2006. p.223

${ }^{32}$ Ibid. P.7
} 
física e psíquica, a privacidade etc., que poderiam ser gravemente afetados pelo mau uso da liberdade de pesquisa científica." 33

Uma forma de solucionar estes conflitos de princípios é sopesar bens, valores, interesses e normas através da ponderação. Em sentido estrito, pode-se definir esta operação hermenêutica como a técnica de decisão pela qual o operador jurídico contrapesa, a partir de um juízo dialético, os bens e interesses juridicamente protegidos.

Se de um lado a existência de princípios já consolidados facilita de algum modo o trabalho do legislador, do intérprete e do aplicador do biodireito, de outro, a diversidade da matéria, sua extrema complexidade e sua larga abrangência, sem dúvida, vão lhe exigir profundo conhecimento da ciência e do sistema jurídico que poderão fornecer elementos para soluções mais adequadas. ${ }^{34}$

${ }^{33}$ DINIZ, Maria Helena. O Estado Atual do biodireito. $2^{\mathrm{a}}$ ed. São Paulo: Saraiva, 2002. p.7

${ }^{34}$ BARBOZA, Heloisa Helena, Princípios do Biodireito. IN. Novos temas de Biodireito e Bioética. Org. Heloisa Helena Barboza ET AL. Rio de Janeiro: Renovar, 2005. P.49 


\section{CAPÍTULO II}

\section{AS TÉCNICAS DE REPRODUÇÃO ASSISTIDA}

\subsection{CONSIDERAÇÕES INICIAIS}

A história da humanidade sempre revelou uma intensa preocupação com a questão da fecundidade. Desde o início das civilizações a reprodução humana sempre foi um tema em destaque, devido à necessidade do homem em dar seguimento à descendência familiar, de transmitir sua tradição, seu nome e seus valores. ${ }^{35}$

Diante da busca de realização do ser humano e até mesmo de cobranças sociais e religiosas foram sendo feitas ao longo do tempo pesquisas em vários segmentos científicos como a Medicina, Biologia e Genética com o objetivo de encontrar uma solução para o problema da infertilidade. ${ }^{36}$

A evolução na medicina pode ser evidenciada tanto pelo advento das técnicas de contracepção, que separam o exercício sexual da procriação, como pelo das novas tecnologias conceptivas, que evidenciam a desvinculação total entre sexo e reprodução.

Atualmente, o casal que deseja ter filhos e não consegue obter resultado através da reprodução natural pode recorrer a intervenções clínicas e/ ou cirúrgicas, ou à técnicas de reprodução artificial, também chamadas de reprodução humana medicamente assistida.

\footnotetext{
${ }^{35}$ PÁDUA, Amélia do Rosário Motta de. Responsabilidade Civil na reprodução Assistida. Rio de Janeiro: Lumen Júris, 2008. p.56.

${ }^{36}$ Ibid.
} 
Quanto ao meio de inseminação, as técnicas se dividem em dois grupos. As intracorpóreas otimizam o encontro dos gametas dentro do organismo feminino como a inseminação artificial e a Transferência Intratubária de Gametas(GIFT) e as extracorpóreas são técnicas de ectogênese, nas quais o encontro dos gametas é feito no laboratório, como a fertilização in vitro e na maternidade por substituição.

Classificando quanto à origem do material reprodutivo, as técnicas podem ser homóloga (material procede do próprio casal que tem o projeto parental), heteróloga (material reprodutivo é doado) ou de "mistura bisseminal" (mistura-se partes do esperma do marido ou companheiro e partes do doador, devido a insuficiência de espermatozóides na ejaculação).

Segundo Maria Berenice Dias "todos esses avanços ocasionaram uma reviravolta nos vínculos de filiação. Todo o antigo sistema de presunções da paternidade, da maternidade e da filiação entrou em ruinas". ${ }^{37}$

Hodiernamente o parentesco não mantém, necessariamente, correspondência com o vínculo consangüíneo. Cabe ao direito identificar o vínculo de parentesco entre pai e filho como sendo o que confere a este a posse de estado de filho e ao genitor as responsabilidades decorrentes do poder familiar.

O Código Civil no artigo 1.597 presume como concebidos na constância do casamento os filhos: havidos por fecundação artificial homóloga, mesmo que falecido o marido; a qualquer tempo, quando se tratar de embriões excedentários, decorrentes de concepção artificial homóloga; e havidos por inseminação artificial heteróloga, desde que exista prévia autorização do marido.

\footnotetext{
${ }^{37}$ DIAS. Maria Berenice. Manual de Direito das Famílias. $4^{\mathrm{a} e d . ~ S a ̃ o ~ P a u l o: ~ R e v i s t a ~ d o s ~ T r i b u n a i s, ~}$ 2007. p. 320
} 


\subsection{A EVOLUÇÃO HISTÓRICA DAS TÉCNICAS DE REPRODUÇÃO ASSISTIDA ${ }^{38}$}

A esterilidade humana sempre foi considerada como um grande problema e, por outro lado, a fertilidade sempre foi vista como uma bênção, como uma forma de "imortalidade".

Até o final do século XV, somente a mulher era considerada estéril, sendo inconcebível a admissão de esterilidade do homem. Somente no século XVII foi admitido que o homem também pudesse ser estéril.

No final do século XIX, pesquisadores concluíram que a fertilização se dava com a união de um espermatozóide com um óvulo através da relação sexual.

Somente no século XX, com o conhecimento médico mais avançado, é que foram realizadas grandes descobertas no campo da genética e a década de 70 foi decisiva para a evolução da reprodução artificial.

Em 1953, os cientistas ingleses James B. Watson e Francis H. C. Crick descobriram a estrutura do DNA, descoberta esta considerada como o marco inicial da engenharia genética.

Entre 1970 e 1975, diversos cientistas realizaram estudos sobre a fertilização in vitro com óvulos humanos, mas foi no final da década de 70 que o primeiro bebê de proveta nasceu na Inglaterra. Após numerosos estudos, o cientista R.G. Edwargs e sua equipe viram nascer, em 1978, no Oldham General Hospital, em Manchester, Louise Brown, o primeiro bebê de proveta a vir à luz na história da humanidade.

\footnotetext{
${ }^{38}$ FERNANDES, Silvia da Cunha Fernandes. As Técnicas de Reprodução Humana Assistida e a Necessidade de sua regulamentação Jurídica. Rio de Janeiro: Renovar, 2005. p. 23.
} 
Desde o nascimento do primeiro "bebê de proveta", a biomedicina e pouco a pouco, toda a sociedade vivenciaram uma mudança repentina, transcendental para muitos, com consequiências então imprevistas. É que, embora sempre tenha havido casais estéreis, através do desenvolvimento da fecundação in vitro e técnicas afins, a resignação deu lugar à esperança. ${ }^{39}$

Atualmente, para quase todos os tipos de esterilidade existe uma técnica apropriada. A seguir discorreremos sobre as modalidades mais comuns de técnicas de reprodução humana assistida.

\subsection{AS TÉCNICAS DE REPRODUÇÃO HUMANA ASSITIDA 2.3.1 INSEMINAÇÃO ARTIFICIAL}

Esta foi a primeira técnica de reprodução humana que se teve notícia. É um processo simples e de custo baixo que visa otimizar a gravidez e consiste na tentativa de fecundar uma mulher por via diferente da relação sexual, introduzindo sêmen no interior de seu aparelho reprodutor.

O sêmen é preparado e colocado dentro do útero da mulher devendo conter uma quantidade adequada de espermatozóides para que completem o trajeto até os óvulos.

A inseminação artificial reproduz as condições fisiológicas da relação sexual. Dependendo do local onde é feita a deposição dos espermatozóides, pode ser: intra-cervical, intra-uterina, intra-peritonal, tubária direta e tubária indireta. ${ }^{40}$

\footnotetext{
${ }^{39}$ BOLZAN, Alejandro D. Reprodução Humana Assistida e dignidade humana. São Paulo: Paulinas, 1998, p.7

${ }^{40}$ PÁDUA, Amélia do Rosário Motta de. Responsabilidade Civil na reprodução Assistida. Rio de Janeiro: Lumen Júris, 2008 p.72
} 


\subsubsection{TRANSFERÊNCIA INTRATUBÁRIA DE GAMETAS (GIFT)}

A Transferência Intrafalopiana de Gametas (GIFT- Gamet Intrafalopean Transfer) consiste na introdução do sêmen nas trompas de falópio e a fecundação é também natural. Consiste em obter os oócitos e os espermatozóides (gametas) para serem introduzidos nas trompas para que ali- onde ocorre naturalmente a fecundação - possa acontecer o processo de fertilização. $^{41}$

Normalmente esta técnica é escolhida por casais que não desejam a concepção em laboratório, por questões morais ou religiosas.

\subsubsection{FERTILIZAÇÃO IN VITRO (FIVETE)}

A fertilização "in vitro", também conhecida como bebê de proveta, é a união do espermatozóide com o óvulo no laboratório, formando o embrião que posteriormente será transferido para cavidade uterina. ${ }^{42}$

Existem duas técnicas a FIV clássica em que se coloca um óvulo em contato com vários espermatozóides e a ICSI em que se injeta um espermatozóide dentro do óvulo.

A técnica consiste em estimular a indução de ovulação, através de medicação, extrair o óvulo maduro de dentro do ovário da mulher e colher o sêmen do genitor. No laboratório, os óvulos são colocados em um recipiente com os espermatozóides (FIV clássica). Na ICSI apenas um espermatozóide é injetado dentro do óvulo ocorrendo a fecundação e formando o zigoto ( pré-embrião).

\footnotetext{
${ }^{41}$ Ibid. P. 73

${ }^{42}$ http://www.projetobeta.com.br acesso em 20/04/2009
} 
Após dois ou três dias a paciente retorna para transferência embrionária. Os embriões são colocados dentro do útero com um catéter especial (tubo plástico). Após 12 a 14 dias já se pode saber o resultado através do teste de gravidez

\subsubsection{MATERNIDADE DE SUBSTITUIÇÃO}

A gestação substituta é popularmente conhecida como "barriga de aluguel" ou "mãe de aluguel". Nestes casos, dissociam-se o desejo da maternidade e a gravidez relativamente à mulher que forma o casal com seu marido ou companheiro, através de uma cessão temporária de útero.

As controvérsias a respeito da utilização das mães de substituição são imensas, dando ensejo a grandes embates no campo religioso, ético e jurídico. No campo jurídico, tal possibilidade se revela prática inimaginada pela legislação.

No entanto, Resolução do Conselho Regional de Medicina admite a cessão temporária do útero sem fins lucrativos, desde que a cedente seja parente até o segundo grau (ou seja, mãe, avó, neta, ou irmã) da mãe genética. $^{43}$

Segundo Maria Berenice Dias, maternidade de substituição gerou alterações nos vínculos de filiação e presunções de maternidade.

" a possibilidade de uso de útero alheio elimina a presunção mater semper certa est, que é determinada pela gravidez e pelo parto. Em conseqüência, também cai por terra a presunção pater est, ou seja, que o pai é o marido da mãe. Assim, quem dá a luz não é a mãe biológica e, como o filho não tem a sua carga biológica, poderia ser considerada, na classificação legal( CC 1.593), como "mãe civil".,"

\footnotetext{
${ }^{43}$ Resolução CFM 1.358/1992, VII

${ }^{44}$ DIAS. Maria Berenice. Manual de Direito das Famílias. 4ª ed. São Paulo: Revista dos Tribunais, 2007. p
} 


\subsection{ASPECTOS JURÍDICOS DA REPRODUÇÃO HUMANA ASSISTIDA}

No Brasil, ainda não existe uma legislação infraconstitucional específica que trate da utilização e os efeitos da reprodução humana assistida.

Em relação ao tema deve-se observar a Resolução $\mathrm{n}^{\circ} 1.358{ }^{45}$, de 11/11/1992, do Conselho Federal de Medicina que adota normas éticas como dispositivo deontológico no que diz respeito à regulamentação e procedimentos a serem observados pelas clínicas e médicos que lidam com a reprodução humana assistida. No entanto, a referida Resolução não se assemelha a disposições com força de lei.

No Congresso Nacional tramitam projetos de lei sobre a reprodução humana assistida, mas alguns foram arquivados sem aprovação. Entre esses projetos podemos destacar o PLS $n^{\circ} 90^{46}$, de março de 1999, que previa como obrigatório o consentimento livre e informado.

A maioria desses projetos, bem como a Resolução CFM n ${ }^{\circ}$ 1.358/92, determinam que a utilização das técnicas deve-se restringir ao auxílio na resolução de problemas de infertilidade. Mas, deixam muito a desejar em relação a vários aspectos do tema.

Em 3 de junho de 2003, foi apresentado ao Congresso Nacional o PL $\mathrm{n}^{\mathrm{o}} 1.184^{47}$, de autoria do Senado Federal, que dispõe sobre a reprodução humana assistida, definindo normas para a realização de inseminação artificial e fertilização in vitro. Em 13 de fevereiro de 2004, a Comissão de

\footnotetext{
${ }^{45}$ A íntegra deste projeto encontra-se no Anexo II desta obra.

${ }^{46}$ A íntegra deste projeto encontra-se no Anexo III desta obra.

${ }^{47}$ A íntegra deste projeto encontra-se no Anexo IV desta obra.
} 
Constituição e Justiça (CCJC) designou o relator do projeto, que devolveu o projeto para a CCJC sem manifestação.

Este projeto parece ser o mais estruturado e adequado à realidade que os demais. Contudo, infelizmente, apesar da evolução em relação à propositura de uma legislação infraconstitucional que regule a utilização das técnicas de reprodução assistida, ainda falta embasamento técnico e humano para se tratar dessas questões.

Vale mencionar ainda, que em 1995 foi elaborada a Lei 8.974, chamada de Lei de Biossegurança, que regulamenta, entre outras coisas, as experiências com embriões humanos, células reprodutivas, material genético, indicando o princípio de indisponibilidade de material biológico e da pessoa.

A referida lei, em seu art. $5^{\circ}$, admite para fins de pesquisa e terapia, a utilização de células-tronco embrionárias obtidas de embriões humanos produzidos por fertilização in vitro, e não usados no procedimento. Esses embriões devem ser inviáveis, ou estarem congelados há três ou mais anos, uma vez que seriam diagnosticados como impróprios para a vida.

Foi proposta pelo Procurador Geral da República, Ação Direita de Inconstitucionalidade contra o citado art. $5^{\circ}$ da Lei de Biossegurança (ADI/3510). Em julgamento de grande repercussão, o Supremo Tribunal Federal decidiu, por maioria, em maio de 2008, pela improcedência do pedido formulado, entendendo pela constitucionalidade de pesquisa e terapia com a utilização de células-tronco embrionárias, nas condições acima referidas.

Ao se pretender legislar sobre reprodução assistida, deve-se, antes de qualquer coisa, partir de princípios éticos e constitucionais básicos de 
respeito à dignidade da pessoa humana, bem como dos princípios gerais de direito universalmente consagrados.

A mestra em Direito Civil, Silvia da Cunha Fernandes, na publicação de sua tese As Técnicas de Reprodução Humana Assistida e a Necessidade de sua Regulamentação Jurídica, propõe algumas sugestões de lege ferenda para uma legislação que regule a utilização dessas técnicas. ${ }^{48}$

Dentre as diversas sugestões, a autora expõe a restrição da utilização da fecundação in vitro a fim de evitar a criação de embriões excedentes; exigência de declaração médica do diagnóstico de esterilidade do casal; indicação de responsabilidade civil de todos os envolvidos nos procedimentos de reprodução artificial; etc.

Assim, enquanto não houver uma legislação específica e abrangente sobre o tema, devem ser observadas as Resoluções do Conselho de Medicina e o profissional da saúde deve observar o Código de Ética Médica, nos seguintes termos:

"É vedado ao médico:

Art.67 - Desrespeitar o direito do paciente de decidir livremente sobre os métodos contraceptivos ou conceptivos, devendo o médico sempre esclarecer sobre a indicação, a segurança, a reversibilidade e o risco de cada método.

Art.68 - Praticar fecundação artificial sem que os participantes estejam de inteiro acordo e devidamente esclarecidos sobre o procedimento.

Art. 122 _ Participar de qualquer tipo de experiência no ser humano com fins bélicos, políticos, raciais ou eugênicos."

Desta forma, o profissional da saúde deve se pautar no senso ético e profissional para que os seus procedimentos e técnicas não sejam alvos de lides judiciais, em especial responsabilização na esfera cível.

\footnotetext{
${ }^{48}$ FERNANDES, Silvia da Cunha. As Técnicas de Reprodução Humana Assistida e a Necessidade de sua Regulamentação Jurídica. Rio de Janeiro: Renovar, 2005.p.179.
} 


\section{CAPÍTULO III}

\section{A RESPONSABILIDADE CIVIL}

\subsection{NOÇÕES GERAIS}

O direito, desde os seus primórdios, visa regular o comportamento humano, impondo regras de conduta, de modo a tornar possível a convivência em sociedade. Para atingir tal objetivo, a ordem jurídica estabelece deveres que podem ser positivos ou negativos.

Enquanto a Medicina busca, através de seus avanços, o equilíbrio vital, que é a saúde do paciente, o direito, paralelamente, busca obter esse mesmo equilíbrio resguardando bens e valores em conflito, que implicam na própria vida e saúde das pessoas, através da proteção constitucional aos direitos fundamentais, assegurando sanção e reparação pelo dano material ou moral, decorrente de sua violação. ${ }^{49}$

O vocábulo "responsabilidade" é definido por Plácido e Silva: "responsabilizar-se, vir garantindo, assumir o pagamento do que se obrigou ou do que praticou. Em sentido geral, pois, responsabilidade exprime a obrigação de responder por alguma coisa." 50

Os princípios jurídicos em que se funda a responsabilidade civil, para efeito de determinar a reparação do dano injustamente causado, provém da máxima velha romana inserta no neminem laedere (não lesar a ninguém). ${ }^{51}$

\footnotetext{
${ }^{49}$ LUZ, Newton Wiethorn da;NETO, Francisco José Rodrigues de Oliveira. Ato Médico: Aspectos Éticos e legais. Rio de Janeiro: Rubio, 2002. P.

${ }^{50}$ SILVA, de Plácido e. Vocabulário Jurídico. $23^{\mathrm{a}}$ ed. Rio de Janeiro: Forense, 2003. p.1222

${ }^{51}$ Ibid. P.1223
} 
A atividade médica manifesta-se através do denominado ato médico, que por natureza e definição é uma ação. Devido aos seus reflexos e possíveis conseqüências no mundo jurídico torna-se necessária sua regulamentação. ${ }^{52}$

A finalidade da responsabilidade civil para o jurista Paulo Nader é a de reparação, prevenção de danos e punição, conforme leciona:

"A responsabilidade civil decorre do descumprimento de um dever jurídico básico definido e imposto em lei ou convenção. Assim, o agente ao violar o dever jurídico pratica ilícito extracontratual ou contratual. Haverá a responsabilidade, ou seja, o dever de reparar em caso de dano ou conforme condições previstas em ato negocial. ${ }^{, 53}$

Haverá responsabilidade contratual, também chamada de ilícito contratual ou relativo, se preexistente uma relação jurídica entre as partes; por outro lado, se o dever jurídico violado não estiver previsto em contrato, mas sim na lei ou na ordem jurídica, a responsabilidade será extracontratual ou aquiliana. ${ }^{54}$

Assim, por exemplo, se alguém atropela um homem que, no acidente perde um braço, o agente causador desse dano fica obrigado a repará-lo e sua responsabilidade é extracontratual. A indenização a ser paga não corresponde à devolução do braço perdido, apenas substitui, em dinheiro, aquilo que aproximadamente se calcula tenha sido o prejuízo da vítima do ato ilícito. ${ }^{55}$

\footnotetext{
${ }^{52}$ LUZ, Newton Wiethorn da; NETO, Francisco José Rodrigues de Oliveira. Ato Médico: Aspectos Éticos e legais. Rio de Janeiro: Rubio, 2002 Prefácio

${ }^{53}$ NADER, Paulo. Curso de Direito Civil.vol. $71^{\text {a }}$ ed. Rio de Janeiro: Forense, 2008. p.9

${ }^{54}$ FILHO, Sergio Cavaleiri. São Paulo.Editora Atlas S.A. 7 a edição. 2007 p.15.

${ }^{55}$ BARATA, Maria Eliza Mazolla. A responsabilidade civil do médico. Rio de Janeiro. 1981. 164p. Dissertação de Mestrado - Departamento de Ciências Jurídicas da PUC- Rio
} 
Por outro lado, na responsabilidade contratual a indenização é, por igual, um substituto da prestação contratada. Quando um artista, contratado para uma série de apresentações, se recusa a dar um ou mais dos recitais combinados, fica ele sujeito a reparar as perdas e danos experimentados pelo empresário. A indenização abrangerá todos os prejuízos efetivos, bem como o lucro que o empresário poderia ter tido.

Em relação ao agente, a responsabilidade civil pode ser direta ou indireta. Quando o dano é provocado por ato do próprio agente a quem é imputada a obrigação pessoal, tem-se a responsabilidade direta encontrada no art. 942 do CC/02, que mantém a responsabilidade solidária a todos que participem da autoria do dano.

$\mathrm{Na}$ responsabilidade indireta responde-se pelo descumprimento de obrigação de outrem, seja em razão de obrigação legal, nos termos do art.932 CC/02, ou em nome do qual exerce a atividade que provocou o dano. Isto ocorre com os pais em relação aos seus filhos, aos tutores, curadores, donos de hotéis e hospedarias entre outros.

A função da responsabilidade civil tem íntima relação com o sentimento de justiça, para Sergio Cavalieri Filho, que assim afirma:

“ O dano causado pelo ato ilícito rompe o equilíbrio jurídico-econômico anteriormente existente entre o agente e a vítima. Há uma necessidade fundamental de se restabelecer esse equilíbrio, o que se procura fazer recolocando o prejudicado no statu quo ante. Impera neste campo o princípio da restitutio in integrum, isto é, tanto quanto possível, repõe-se a vitima à situação anterior à lesão. Isso se faz através de uma indenização fixada em proporção ao dano." $" 56$

Nas palavras de Maria Helena Diniz, é dupla a função da responsabilidade:

\footnotetext{
${ }^{56}$ FILHO, Sergio Cavalieri. Programa de Responsabilidade Civil. $7^{\mathrm{a}}$ ed. São Paulo:Atlas S.A., 2007.p.13.
} 
"A responsabilidade civil constitui uma sanção civil, por decorrer de infração de norma de direito privado, cujo objetivo é o interesse particular, e, em sua natureza é compensatória, por abranger indenização ou reparação de dano causado por ato ilícito, contratual ou extracontratual e por ato ilícito." 57

Vale mencionar que o estudo da responsabilidade civil abrange todo o conjunto de princípios e normas que regem a obrigação de indenizar, nos seguintes termos, conforme disserta o autor Sílvio Venosa:

" Os princípios da responsabilidade civil buscam restaurar um equilíbrio patrimonial e moral violado. Um prejuízo ou um dano não reparado é um fator de inquietação social. Os ordenamentos contemporâneos buscam alargar cada vez mais o dever de indenizar, alcançando novos horizontes, a fim de que cada vez menos restem danos irressarcidos. ${ }^{\circ 5}$

Após esta breve análise, pode-se concluir que a responsabilidade civil pode ser direta ou indireta. Além disso, é possível dividi-la em responsabilidade contratual, prevista nos arts. 389 e $475 \mathrm{CC} / 02$, cuja obrigação pode ser de meio ou de resultado, e responsabilidade extracontratual, que se divide em responsabilidade subjetiva e objetiva, cujas principais características serão vistas a seguir.

\subsection{A RESPONSABILIDADE SUBJETIVA E A RESPONSABILIDADE OBJETIVA}

No parecer de Silvio Rodrigues, a responsabilidade objetiva e subjetiva não são espécies diversas de responsabilidade, mas apenas maneiras diferentes de encarar a obrigação de reparar o dano. ${ }^{59}$ Diz-se ser subjetiva a responsabilidade quando se inspira na idéia de culpa e objetiva quando esteada na Teoria do Risco.

${ }^{57}$ DINIZ. Maria Helena. Curso de Direito Civil Brasileiro vol. 7. $18^{\mathrm{a}}$ ed. São Paulo: Saraiva, 2004. p.8.

${ }^{58}$ VENOSA, Sílvio de Salvo. Direito Civil vol.4.5 ${ }^{a}$ ed.São Paulo: Atlas, 2005. p.14.

59 RODRIGUES. Silvio. Direito Civil vol. 4. São Paulo:Saraiva. 2003. p.11 
A idéia de responsabilidade sempre esteve ligada à culpa, conduta voluntária do agente, motivo pelo qual este é o principal pressuposto da responsabilidade civil subjetiva, de acordo com a Teoria Clássica.

Os requisitos essenciais, pressupostos capazes de gerar a obrigação de indenizar, podem ser depreendidos mediante leitura do art. 186 do Código Civil, quais sejam, a conduta culposa do agente, o nexo causal e o dano.

Já era esse o entendimento de Sérgio Cavaliere Filho ao mencionar que "há primeiramente um elemento formal, que é a violação de um dever jurídico mediante conduta voluntária; um elemento subjetivo, que pode ser dolo ou a culpa; e ainda, um elemento causal-material, que é o dano e a respectiva relação de causalidade.${ }^{60} \mathrm{~A}$ seguir analisaremos cada um desses elementos.

A conduta é o comportamento humano voluntário, exteriorizado através de uma ação, comissiva ou omissiva, qualificada juridicamente. Esta conduta deve ser culpável, ou seja, reprovável.

Para ocorrer essa censurabilidade da conduta, é necessário que o agente seja imputável, tenha maturidade e sanidade mental, a fim de entender o caráter de sua conduta e determinar-se de acordo com esse entendimento.

A noção de culpa deve ser entendida em sentido amplo (lato sensu) e abrange toda espécie de comportamento contrário ao Direito, seja intencional, no caso de dolo, ou não, como na culpa em que ocorre o

\footnotetext{
${ }^{60}$ FILHO, Sergio Cavalieri. Programa de Responsabilidade Civil. $7^{\mathrm{a}}$ ed. São Paulo:Atlas S.A., 2007.p.17.
} 
descumprimento de um dever de cuidado, seja por imprudência, negligência ou imperícia.

Além disso, só será responsabilizado por omissão quem tiver o dever jurídico de agir, ou seja, obrigação de evitar o resultado em determinada situação jurídica. Assim, por exemplo, os pais têm o dever legal de alimentar os filhos, então somente eles respondem pela omissão alimentar daqueles. Da mesma forma, somente o médico contratado pelo paciente, ou que está responsável pelo atendimento, responde pela falta deste atendimento, pois assumiu a posição de garantidor.

O nexo de causalidade é entre o dano e a ação (fato gerador da responsabilidade). Como a responsabilidade civil não pode existir sem o vínculo entre a ação e o dano, podemos conceituar o nexo causal como a relação de causa e efeito entre a conduta e o resultado.

Não haverá nexo causal se ocorrer algumas das excludentes, quais sejam, culpa exclusiva da vítima, culpa concorrente, culpa comum, culpa de terceiro, força maior ou caso fortuito.

Existem diversas construções dogmáticas, destacando-se a Teoria da Causalidade Adequada, Teoria da Equivalência das Condições e a Teoria de interrupção do nexo causal. Mas, segundo lição de Sergio Cavalieri, os nossos melhores autores sustentam que a Teoria da Causalidade Adequada é que prevalece na esfera cível. ${ }^{61}$ Assim, em sede de responsabilidade civil, nem todas as condições que concorrem para o resultado são equivalentes, mas somente aquela que foi a mais adequada a produzir o resultado concretamente.

${ }^{61}$ Ibid. 
Desta forma, diante de uma pluralidade de causas, imputa-se o dever de reparar à causa que seja vinculada ao dano por uma relação de necessariedade, o que equivale, em regra, ao dano direto e imediato. ${ }^{62}$ Isto pode ser observado em decisão do TJRJ que invocou a teoria da causalidade adequada.

EMENTA: responsabilidade civil. Estabelecimento Hospitalar. Remoção de paciente por meio inadequado. Morte da parturiente durante remoção. Responsabilidade do hospital que deu a autorização. Se o evento não teria ocorrido sem a conduta praticada pelo agente, que seja essa relação apreciada no plano concreto, quer no plano abstrato, impõe-se concluir pela existência do nexo causal. Assim, provado ter a clínica médica permitido que familiares a removessem em condições precárias para outro hospital, vindo esta a falecer no curso da remoção, resulta inquestionável que essa autorização foi a causa adequada do evento, posto que sem ela o resultado não teria ocorrido. Resulta também evidenciada a negligência do estabelecimento hospitalar porque, ciente da gravidade do estado da parturiente, jamais poderia permitir a sua remoção em condições precárias.Desprovido o Recurso. ${ }^{63}$

Por fim, o dano pode ser definido como violação de direito alheio. É lesão (diminuição ou destruição) que, devido a um evento certo, sofre uma pessoa, podendo ser patrimonial ou moral. Não há que se falar em responsabilidade civil sem dano, que deve ser certo, a um bem ou interesse jurídico, sendo necessária a prova concreta e real dessa lesão.

O dano patrimonial ou material corresponde a um desfalque no patrimônio do indivíduo. Abrange o dano emergente (o que o lesado efetivamente perdeu) e lucro cessante (o aumento que seu patrimônio teria, mas deixou de ter, em razão do evento danoso).

Destarte, nem todos os prejuízos causados às vítimas são de natureza material. O dano moral, por sua vez, refere-se a bens imateriais que não são suscetíveis de avaliação pecuniária como a vida, a honra e a liberdade. Uma

\footnotetext{
${ }^{62}$ TEPEDINO, Gustavo et al.. Código Civil Intrepretado: Conforme a Constituição da Republica. São Paulo: Renovar, 2004. p. 339.

${ }^{63}$ TJRR, Apelação no 199700101528 , Rel. Des.Sergio Cavalieri Filho, Rio de Janeiro, 29.04.1997
} 
vez atingidos estes valores humanos, provocam sofrimento, angústia, desespero e impõem reparação.

Atualmente encontra-se superada a controvérsia sobre a reparabilidade do dano moral, que já foi consagrada pelo direito positivo e pelos Tribunais. ${ }^{64}$

Não obstante, é possível a cumulabilidade entre dano material e dano moral, nos termos da Súmula 37 do STJ, que estabelece: "São cumuláveis as indenizações por dano material e dano moral oriundas do mesmo fato".

Vistos os elementos da responsabilidade subjetiva, pode-se observar que a mesma não satisfaz plenamente ao anseio de justiça nas novas relações sociais advindas da modernidade e do desenvolvimento industrial. O crescimento populacional gerou novas situações que ficavam desamparadas devido ao conceito tradicional de culpa. ${ }^{65}$ Assim houve um retorno a antiga idéia romana em que não era necessário averiguar a culpa como ocorria na Lei de Talião "olho por olho dente por dente".

Desta forma, visando uma solução para as atividades no mundo dos negócios que implicam riscos para a incolumidade física e patrimonial das pessoas, o pensamento jurídico concebeu a Teoria do Risco ou Responsabilidade Objetiva para resguardar as vítimas. O legislador estabeleceu presunções a favor do ofendido em certos tipos de lesões, em que há dificuldade de se provar a culpa, nos termos do art. 927 , art.931 e outros do Código Civil. ${ }^{66}$

\footnotetext{
${ }^{64}$ Ibid.

${ }^{65}$ FILHO, Sergio Cavalieri. Programa de Responsabilidade Civil. $7^{a}$ ed. São Paulo:Atlas S.A., 2007.p.16

${ }^{66}$ NADER, Paulo. Curso de Direito Civil. Vol. 7. Rio de Janeiro: Forense, 2008, p.30
} 
Maria Helena Diniz filia-se a idéia de que a responsabilidade objetiva funda-se num princípio da equidade existente desde o direito romano:

“Aquele que lucra com uma situação deve responder pelo risco ou pelas desvantagens dela resultantes( ubi emolumentum, ibi ônus; ibi incommoda). Essa responsabilidade tem como fundamento a atividade exercida pelo agente, pelo perigo que pode causar dano à vida, à saúde ou outros bens, criando risco de danos a terceiros." 67

Resta evidente que a principal distinção entre a responsabilidade subjetiva e a objetiva reside no elemento "culpa". Por outro lado, o autor Paulo Nader destaca a semelhança entre as duas responsabilidades: "Na responsabilidade subjetiva e objetiva há um denominador comum: a ocorrência de danos e o nexo de causalidade entre a conduta do ofensor e as conseqüências nocivas à vítima." 68

Importante mencionar que a Teoria Objetiva não substituiu a Teoria Subjetiva fundada na culpa e ambas convivem no ordenamento jurídico. A regra geral é a Teoria Subjetiva, e a Teoria Objetiva atende a casos específicos, para os quais a teoria tradicional se revela insuficiente.

No entanto, Sergio Cavalieri afirma que essa posição ficou abalada com a vigência do Código do Consumidor, Lei $\mathrm{n}^{\circ}$ 8.078/90, nos seguintes termos:

"Tudo ou quase tudo em nossos dias tem a ver com o consumo, de sorte que não haverá nenhuma impropriedade em se falar hoje a responsabilidade objetiva, que era exceção, passou a ter um campo de incidência mais vasto do que a própria responsabilidade subjetiva." ${ }^{69}$

\footnotetext{
${ }^{67}$ DINIZ. Maria Helena. Curso de Direito Civil Brasileiro vol. $7.18^{\text {a }}$ ed. São Paulo: Saraiva,2004.p.55.

${ }^{68}$ NADER, Paulo. Curso de Direito Civil. Vol. 7. Rio de Janeiro: Forense, 2008, p.31.

${ }^{69}$ FILHO, Sergio Cavalieri. Programa de Responsabilidade Civil. $7^{\mathrm{a}}$ ed. São Paulo:Atlas S.A., 2007.p. 25
} 


\subsection{A RESPONSABILIDADE PROFISSIONAL DO MÉDICO}

\subsubsection{NATUREZA JURÍDICA:}

O vínculo que une médico e paciente é contratual, pois de um lado temos uma pessoa (paciente) que procura serviços especializados de um profissional para atender seu problema de saúde e de outro temos o profissional detentor de conhecimento especializado para ajudar na cura de seu paciente. ${ }^{70}$

Segundo Maria Helena Diniz "é nítido o caráter contratual, apenas excepcionalmente terá natureza delitual, quando o médico cometer um ilícito penal ou violar normas regulamentares da profissão." 71

Em relação à natureza jurídica da relação contratual entre o médico e o paciente os doutrinadores se dividem em duas posições básicas: contrato de prestação de serviço ou contrato sui generis.

Sergio Cavalieri se posiciona em favor da classificação como um contrato sui generis, isto porque o médico não se limita a prestar serviços estritamente técnicos, acabando por se colocar numa posição de conselheiro, de guardião e protetor do enfermo e seus familiares. ${ }^{72}$

No entanto, Paulo Nader defende em sua obra a classificação do vínculo de contrato de prestação de serviços, pois em razão da massificação dos atendimentos, prestados em convênio com planos de saúde, praticamente desapareceu a figura do médico conselheiro e orientador. ${ }^{73}$

\footnotetext{
${ }^{70}$ FERNANDES, Silvia da Cunha. As Técnicas de Reprodução Humana Assistida e a Necessidade de sua Regulamentação Jurídica. Rio de Janeiro: Renovar, 2005.p.133.

${ }^{71}$ DINIZ. Maria Helena. Curso de Direito Civil Brasileiro vol. 7. $18^{\mathrm{a}}$ ed. São Paulo: Saraiva, 2004.p. 299.

${ }^{72}$ FILHO, Sergio Cavalieri. Programa de Responsabilidade Civil. $7^{\text {a }}$ ed. São Paulo:Atlas S.A., 2007.p. 360

${ }^{73}$ NADER, Paulo. Curso de Direito Civil. Vol. 7. Rio de Janeiro: Forense, 2008, p. 389.
} 
Sílvio Venosa, por sua vez, entende tratar-se de contrato de prestação de serviços, na maioria das vezes, intuito personae, bilateral, de trato sucessivo e oneroso. Ocorre que, em algumas hipóteses, a existência de contrato entre médico e paciente não fica muito clara, como quando um médico assiste transeunte em via pública, ou socorre um vizinho acometido de mal súbito, motivo pelo qual não existe consenso na doutrina. ${ }^{74}$

Apesar da divergência quanto à natureza jurídica, o relevante, no tocante à responsabilidade contratual do médico, é saber se a obrigação gerada pela avença é de meio ou de resultado.

Entende-se por obrigação de meio, aquela em que o profissional se compromete a atuar com toda a prudência e diligência necessárias para a boa execução do ofício, utilizando-se de todos os recursos possíveis a fim de alcançar o objetivo pretendido; porém, sem a ele se vincular. Havendo inadimplemento dessa obrigação deverá ser analisada a conduta do profissional e sua relação com o resultado final.

Já a obrigação de resultado vincula diretamente o profissional à produção do resultado. Assim, não há que se falar em análise da sua conduta e, desta forma, o cliente poderá exigir a produção do resultado inicialmente pretendido, sem o qual ficará caracterizado o inadimplemento da obrigação.

A obrigação do médico, em geral, é de meio. Somente quando agir com negligência, imprudência ou imperícia poderá o profissional ser responsabilizado por sua conduta, tendo o dever de reparar os danos causados a seu paciente. Dessa forma, a responsabilidade do médico, em regra, é subjetiva devido à necessidade da análise da culpa como pressuposto de existência do dever de indenizar.

${ }^{74}$ VENOSA, Sílvio de Salvo. Direito Civil vol.4.5ª ed.São Paulo: Atlas, 2005. p. 114. 
No entanto, em alguns casos, poderá ser obrigação de resultado como a cirurgia plástica, procedimentos técnicos de exame laboratorial, e outros tais como radiografias, tomografias, ressonâncias magnéticas etc. ${ }^{75}$ Nestes casos, a responsabilidade civil médica passará a ser objetiva.

\subsubsection{A RELAÇÃo COM O CÓdigo DE DEFESA DO CONSUMIDOR}

Em matéria de responsabilidade médica é oportuno suscitar a questão sobre a possibilidade de ela ser enquadrada ou não dentro do Código de Defesa do Consumidor.

A proteção do consumidor é definida como de ordem pública e de interesse social, norteando as relações de consumo de maneira homogênea. Parte da doutrina, como o Prof. Gustavo Tepedino, defende a aplicação, nos contratos em geral, dos princípios contidos no diploma do consumidor, reconhecido microssistema de ordenamento civil, isto porque o estatuto do consumidor é norma principiológica que emana da Constituição Federal, e retrata prioridades de valores. ${ }^{76}$

Segundo Cláudia Lima Marques, diante de um eventual conflito de leis, prevalecerá o Código de Defesa do Consumidor que é norma específica em relação ao código civil e tem função social. ${ }^{77}$

\footnotetext{
${ }^{75}$ Ibid. p. 109.

${ }^{76}$ PÁDUA, Amélia do Rosário Motta de. Responsabilidade Civil na reprodução Assistida. Rio de Janeiro: Lumen Júris, 2008.p.156.

${ }_{77}^{77}$ MARQUES, Claudia Lima. Contratos no Código de Defesa do Consumidor. O novo regime das relações contratuais. $5^{\text {a }}$ ed. São Paulo: Revista dos Tribunais, 2005. p.589.
} 
O Código de Defesa do Consumidor é uma legislação avançada, que pretende atender a pessoa que se sujeita a prestação de serviços ou aos fornecedores, sendo claro e direto em relação aos profissionais liberais, nos termos do art.14 $\S 4^{\circ}$.

Assim, como a relação que se estabelece entre o médico e o paciente têm por objeto uma prestação de serviços, não pode sofrer a grave pena de ser afastada da relação consumerista imposta pelo Código de Defesa do Consumidor, que representa um dos maiores instrumentos de proteção e defesa dos direitos fundamentais no âmbito dos contratos. 78

O autor Silvio Rodrigues abraça este entendimento:

"Entre o cirurgião e o paciente se estabelece um contrato tácito em que o cirurgião se propõe a realizar cirurgia na pessoa do paciente, mediante remuneração, e se obriga a usar toda a sua habilidade para alcançar o resultado almejado. Trata-se de contrato de prestação de serviço, pois esse contrato, na linguagem daquele código é toda a atividade fornecida no mercado mediante remuneração( art. $\left.3^{\circ}, \S 2^{\circ}\right)$. Portanto, parece-me que a relação entre paciente e cirurgião fica abrangida pelo Código de Defesa do Consumidor.,"79

Infelizmente, nem todos os autores admitem que a prestação de serviços médicos esteja regulada pelo Código de Defesa do Consumidor. Entre eles, é possível destacar Cleonice Rodrigues Casarin da Rocha, que afirma "o paciente não é um consumidor" 80

\footnotetext{
${ }^{78}$ PÁDUA, Amélia do Rosário Motta de. Responsabilidade Civil na reprodução Assistida. Rio de Janeiro: Lumen Júris, 2008.p.196.

${ }^{79}$ RODRIGUES. Silvio. Direito Civil vol. 4. Ed. Saraiva. 2003. p.254.

${ }^{80}$ ROCHA. Cleonice Rodrigues Casarin da. A responsabilidade Civil Decorrente do Contrato de Serviços Médicos. $1^{\mathrm{a}}$ ed. Rio de Janeiro: Forense. 2005. p.44
} 


\subsubsection{O ÕNUS DA PROVA}

Uma das questões mais nebulosas da responsabilidade do médico é a questão do ônus da prova. A problemática reside no fato de que, em regra, para nascer o dever de indenizar, cabe ao paciente o ônus de provar a culpa (imprudência, imperícia ou negligência) do médico, no exercício de sua atividade. $^{81}$

Os juízes geralmente recorrem à prova pericial para formar sua convicção e emitir juízo de mérito sobre a conduta do profissional. O autor pode e deve eleger assistente técnico para acompanhar o trabalho da perícia médica, a fim de evitar a solidariedade profissional e o corporativismo.

Se o juiz entender que a natureza do caso escapa à capacidade de a parte demonstrar tecnicamente o erro médico, poderá determinar a inversão do ônus da prova prevista no art. $6^{\circ}$, inciso VIII, do Código de Defesa do Consumidor. $^{82}$

Desta forma, fica a critério do juiz verificar a verossimilhança da alegação, ou seja, a probabilidade de ser verdade e a hipossuficiência do consumidor, que pode ser econômica (miserabilidade) ou técnica (impossibilidade do consumidor provar o fato constitutivo do seu direito), podendo inverter o ônus da prova.

Importante mencionar que a inversão do ônus da prova não implica na inversão das custas periciais, que continuam sendo do autor.

\footnotetext{
${ }^{81}$ CRUZ, Alex. A responsabilidade Civil do Médico. MÍDIA JURÍDICA MURAL Direito em Movimento. Rio de Janeiro, n.62, p.6-10, mar. 2009.

${ }^{82}$ NADER, Paulo. Curso de Direito Civil. Vol. 7. Rio de Janeiro: Forense, ANO. p. 309
} 
As decisões judiciais já estão aplicando o Código de Defesa do Consumidor nas relações entre médicos e paciente. Em recente acórdão o Tribunal de Justiça de Minas Gerais admitiu além da aplicação do Código de Consumidor, a possibilidade de inversão do ônus da prova.

Ementa: CIVIL - AÇÃO DE INDENIZAÇÃO - SENTENÇA NULIDADE - INVERSÃO DO ÔNUS DA PROVA - ERRO MÉDICO - PARTO - SUTURA - ATINGIMENTO DO RETO - SURGIMENTO DE FÍSTULA NECESSIDADE DE SUCESSIVAS CIRURGIAS - INCONTINÊNCIA FECAL - NEXO CAUSAL COMPROVADO - REPARAÇÃO DEVIDA - DANOS MATERIAIS - AUSÊNCIA DE PROVA DE DESPESAS - LUCROS CESSANTES - DANO MORAL - VALOR DO RESSARCIMENTO HOSPITAL - RESPONSABILIDADE OBJETIVA E SOLIDÁRIA. "Mantém-se a inversão do ônus da prova quando existe verossimilhança na alegação e há nítido desequilíbrio entre as partes, em ação de indenização que objetiva a discussão de ato ilícito na prática da medicina. A utilização de fundamentos discutidos ao longo da demanda como reforço de fundamentação para exposição do entendimento do Magistrado e procedência do pedido não pode ser considerada ilegal inclusão de causa de pedir. Havendo prova conclusiva e segura de que houve erro por imperícia quando da sutura do corte feito na autora, e do nexo de causalidade entre este erro e a fístula que se originou, que teve por conseqüência a necessidade de realização de mais quatro cirurgias para completa recuperação, é cabível concluir pela responsabilidade civil do médico e do hospital. "'É imprescindível, já na ação de conhecimento, que se comprove, de maneira cabal, em que consistiram, efetivamente, os danos, podendo-se relegar, tão-somente, para a fase de liquidação, a apuração do seu quantum. Não ensejam a condenação os danos meramente prováveis, mas apenas os danos comprovados."" (Apel. Cív. 371.769-5, Rel. Mauro Soares de Freitas). Comprovado o sofrimento, angústia, aflição impingidos na autora em razão do erro médico, correta a condenação ao pagamento de indenização por danos morais, em valor que foi razoavelmente fixado. Agravo retido não provido, preliminares rejeitadas e apelações parcialmente providas. $^{83}$ ( grifos nossos)

Em relação à prescrição da pretensão indenizatória o critério para a fixação do prazo será a natureza da relação jurídica das partes, se de consumo, aplica-se a regra do $\mathrm{CDC}$, se relação civil, a regra do Código Civil.

O código civil, em seu artigo $206 \S 3^{\circ}, \mathrm{V}$, estabelece um prazo prescricional de três anos para a reparação civil. Enquanto que o Código de

\footnotetext{
${ }^{83}$ TJRJ, Apelação nº1.0105.00.015918-3/001, rel: des. Alberto Vilas Boas, Rio de Janeiro,
} 20/10/2006 
Defesa do Consumidor prevê o prazo prescricional de cinco anos para a pretensão à reparação dos danos causados por fato do serviço nos termos do artigo 27 à contar do conhecimento do dano e de sua autoria.

Assim, é possível verificar a importância e benefícios da aplicação da lei $n^{\circ}$ 8.078/90 nas relações entre médico e paciente, seja em relação ao ônus da prova ou em relação à prescrição da pretensão indenizatória que ocorre em prazo maior. 


\section{CAPÍTULO IV}

\section{A RESPONSABILIDADE CIVIL NA REPRODUÇÃO HUMANA ASSISTIDA.}

\subsection{O CONSENTIMENTO LIVRE E ESCLARECIDO}

O termo consentimento informado foi utilizado pela primeira vez em 1967, antes da existência da anestesia, pois sendo imprescindível a colaboração do paciente, era praxe o cirurgião informá-lo sobre o procedimento que adotaria. ${ }^{84}$

O consentimento é considerado ato jurídico capaz de produzir efeitos na órbita do Direito. Dessa forma, o objeto jurídico do consentimento deve ser lícito, isto é, não contrário à lei. Além disso, o paciente deve ter capacidade jurídica para os atos da vida civil no momento de emissão do consentimento. ${ }^{85}$

$\mathrm{O}$ uso do termo consentimento livre e esclarecido pretende que a manifestação de vontade ocorra após pleno conhecimento da situação, suas reais e possíveis consequiências, completamente desprovida de indução, coação ou qualquer outra imposição de natureza interna ou externa.

O Código Civil de 2002, em seu artigo 15, assevera que ninguém pode ser constrangido a submeter-se, com risco de vida, a tratamento médico ou intervenção médica. Tal disposição constitui-se como direito da personalidade, indissociável do indivíduo, e deve ser compreendido como o

\footnotetext{
${ }^{84}$ PÁDUA, Amélia do Rosário Motta de. Responsabilidade Civil na reprodução Assistida. Rio de Janeiro: Lumen Júris, 2008.p.86

85 BARATA, Maria Eliza Mazolla. A responsabilidade civil do médico. Rio de Janeiro. 1981. 92p. Dissertação de Mestrado - Departamento de Ciências Jurídicas da PUC- Rio.
} 
direito de proteger a matéria (corpo) na qual a vida se faz presente, de atos danosos cometidos por terceiros. ${ }^{86}$

Além disso, prevê o nosso ordenamento jurídico que o paciente (o ser humano) tem o direito fundamental à informação. Somente quando o paciente se encontrar em iminente perigo de vida, e não houver tempo hábil para obter o consentimento, é que o médico deverá lutar pela vida e melhores condições do paciente mesmo sem a manifestação de vontade do mesmo.

A propósito, preleciona Paulo Nader:

"Se durante um ato cirúrgico autorizado o médico constata um fato imprevisto e que exige outro tipo de intervenção, admite-se a mudança no plano cirúrgico, desde que a opção e a conduta não contrariem as recomendações da ciência, pois se entende que não seria razoável a suspensão do ato, unicamente para as inovações e obtenção de outro consentimento." ${ }^{87}$

No tocante às técnicas de reprodução artificial o consentimento tem ainda maior relevância, pois constitui a legitimação e fundamentação do ato médico refletindo uma atitude eticamente correta. ${ }^{88}$

O Código de Ética Médica, em seu artigo 68, prevê que é vedado ao médico praticar fecundação artificial sem que os participantes estejam de acordo e devidamente esclarecidos sobre os procedimentos a serem executados. $^{89}$

É necessário provar a conduta culposa do médico para ser caracterizada a responsabilidade devido à falta de informação e

\footnotetext{
${ }^{86}$ CRUZ, Alex. A responsabilidade Civil do Médico. MÍDIA JURÍDICA MURAL Direito em Movimento. Rio de Janeiro, n.62, p.6-10, mar. 2009.

${ }^{87}$ NADER, Paulo. Curso de Direito Civil. Vol. 7. Rio de Janeiro: Forense, 2008, p.395

${ }^{88}$ FERNANDES, Silvia da Cunha. As Técnicas de Reprodução Humana Assistida e a Necessidade de sua Regulamentação Jurídica. Rio de Janeiro: Renovar, 2005. p. 127.

${ }^{89}$ Resolução CFM n ${ }^{\circ} 1.246$
} 
consentimento do paciente. Neste sentido encontra-se a ementa do Tribunal de Justiça de São Paulo:

Ementa: Ação de Indenização por Dano Moral - Erro médico - Falta de comunicação sobre os riscos da cirurgia - Negligência e imprudência médica? Paciente que deixou de produzir espermatozóides - Inexistência da prova da culpa - Recurso Improvido. ${ }^{90}$

\subsection{O SIGILO PROFISSIONAL}

$\mathrm{O}$ direito à intimidade é consagrado no artigo $5^{\circ}$ inciso $\mathrm{X}$ da Constituição Federal. Desta forma, é vedado ao médico divulgar fato de que tenha ciência em razão de seu ofício, salvo justa causa, dever legal ou autorização expressa do paciente, de acordo com a Resolução $n^{\circ} 1.246$ de 08.01.1988, do Conselho Federal de Medicina. ${ }^{91}$

No âmbito da Reprodução Assistida o sigilo médico deve ser analisado sob aspectos regulares da relação médico-paciente. É necessário zelar pelo sigilo da doação, impedindo que doadores e beneficiários venham a conhecer reciprocamente suas identidades, e pelo sigilo das informações sobre a pessoa nascida por processo de Reprodução Assistida. ${ }^{92}$

Também aqui se verifica que o sigilo não é absoluto, apesar de mantidos o segredo profissional e o segredo de justiça. Na opinião de Sergio Cavalieri:

“em situações especiais, pode o médico ser levado a quebrá-lo, mormente quando estiver em jogo outro interesse relevante - salvar a vida do próprio paciente ou de outra pessoa a ele ligada; notificar a doença infecto-contagiosa; apurar fato delituoso; realização de perícias médico-legais e outras requisições da

\footnotetext{
${ }^{90}$ TJSP, Apelação no 5456724500, Rel. Luiz Antonio Costa, São Paulo, 12/03/2008

${ }^{91}$ NADER, Paulo. Curso de Direito Civil. Vol. 7. Rio de Janeiro: Forense, 2008, p.397

${ }^{92}$ PLS 90/99 Art. $8^{\circ}$ Os serviços de saúde que praticam a Reprodução Assistida estarão obrigados a zelar pelo sigilo da doação, impedindo que doadores e beneficiários venham a conhecer reciprocamente suas identidades, e pelo sigilo absoluto das informações sobre a pessoa nascida por processo de Reprodução Assistida.
} 
justiça. Mesmo nesses casos a revelação deve circunscrever-se ao limite do estritamente necessário." ${ }^{, 93}$

O Projeto de Lei do Senado PLS 90/99 dispõe que todas as informações serão sigilosas e limita a possibilidade de revelá-las nos casos previstos em lei, que são: acesso às informações relativas ao processo de RA, pelas pessoas nascidas por ele (mantidos o segredo profissional e de justiça); ou quando razões médicas ou jurídicas indicarem ser necessário à vida ou à saúde da pessoa gerada ou para oposição de impedimento do casamento, sobre informações genéticas do doador, a serem fornecidas ao médico solicitante ou á autoridade que presidirá o casamento, sempre resguardada a identidade civil do doador. ${ }^{94}$

$\mathrm{Na}$ ementa abaixo é possível verificar a possibilidade de quebra no sigilo profissional em razão de justa causa e requisição judicial.

Ementa: Medida cautelar. Ação de exibição de documentos. Caráter satisfativo. Possibilidade. Sigilo profissional. Solicitações de informações detidas por nosocômio. Troca de bebês na maternidade. Prevalência da busca da verdade real sobre o segredo da profissão. Sentença de procedência mantida. Recurso improvido, com determinação. ${ }^{95}$

Supondo que a criança gerada por técnica de RA alegue a necessidade de conhecer sua origem genética, fundamentando-se no direito à identidade (direito da personalidade) em preservação de sua dignidade humana, o médico sensibilizado poderia fornecer os dados solicitados?

Tendo em vista o foco do nosso trabalho, diante do impasse entre direito à intimidade do doador, sigilo profissional e dignidade humana da

\footnotetext{
${ }^{93}$ FILHO, Sergio Cavalieri. Programa de Responsabilidade Civil. $7^{\mathrm{a}}$ ed. São Paulo:Atlas S.A., 2007.p.399.

${ }^{94}$ PLS 90/99 Art. $9^{\circ} \mathrm{O}$ sigilo estabelecido no artigo anterior poderá ser quebrado nos casos autorizados nesta Lei, obrigando-se o serviço de saúde responsável pelo emprego da Reprodução Assistida a fornecer as informações solicitadas, mantido o sigilo profissional e, quando possível, o anonimato.

${ }^{95}$ TJSP, Apelação com revisão n ${ }^{\circ} 3837034800$, Rel. Caetano Lagrasta, São Paulo, 20/02/2008.
} 
criança, à luz da Resolução 1.358 CFM, é vedado ao médico a divulgação da identidade dos doadores de gametas e pré-embriões, sendo permitido apenas o fornecimento de informações sobre os doadores por razões médicas e, exclusivamente para médicos.

Não obstante, uma vez reconhecida a paternidade de filho gerado por inseminação artificial heteróloga não é possível anulá-la, e a criança não terá informação sobre a paternidade biológica.

Ementa:Ação negatória de Paternidade. Pretensão deduzida por quem voluntariamente registrou como sua, filha gerada por inseminação artificial. Adoção simulada ou à brasileira. Incabível a pretensão anulatória do registro de nascimento de filha da mulher, com quem era casado, e que fizera inseminação artificial, eis que o assumido pai era portador de azoospermia. Sentença de improcedência cujos fundamentos se adotam. Recurso improvido. ${ }^{96}$

\subsection{A RESPONSABILIDADE CIVIL DAS CLÍNICAS DE REPRODUÇÃO ASSISTIDA E DOS BANCOS DE DEPÓSITO DE MATERIAL FERTILIZANTE}

$\mathrm{Na}$ atividade médica, o profissional responde diretamente pelos atos praticados que causem dano ao paciente. No entanto, é possível que ocorra obrigação de indenizar por via indireta ou reflexa, sendo responsável o empregador ou comitente, por seus empregados e prepostos, no exercício do trabalho que lhes competir, ou em razão dele, prevista no artigo 932 inciso III do Código Civil.

Trata-se da responsabilidade por fato de terceiro, em que podemos vislumbrar dois agentes, o causador do dano e o responsável pela indenização.

\footnotetext{
${ }^{96}$ TJRJ, Apelação n⿳ 2006.001.12185, Rel. Des. Jose Carlos Varanda, Rio de Janeiro, 28/06/2006.
} 
Os hospitais e clínicas têm o dever de prestar assistência médica hospitalar e de hospedagem, sendo responsáveis pelos fatos danosos cometidos por seus funcionários, pelos danos à incolumidade dos pacientes e pela omissão de diligências necessárias à prestação dos serviços hospitalares. ${ }^{97}$ Essa responsabilidade da clínica ou do hospital pelas ações dos profissionais que nele exercem atividades decorre da culpa in vigilando.

Em razão da idéia de risco, os hospitais e clínicas, pessoas jurídicas de direito privado, sempre estiveram inseridas na responsabilidade objetiva sem qualquer tipo de discussão em contrário.

Ocorre que em razão da especificidade do Código de Defesa do Consumidor, já visto anteriormente, os hospitais têm sido enquadrados como fornecedores de serviço incidindo o $§ 1^{\mathrm{a}}$ do artigo 14 do CDC.

Assim, uma vez percebida a incongruência que seria considerar a pessoa jurídica responsável sempre que houvesse um dano, a jurisprudência tem começado a trilhar um caminho mais justo e equânime. Hildegard Taggesell Giostri enumera três motivos para tal fato:

Em primeiro lugar esta entidade pode responder sem culpa, mas não pode responder sem causa. Em segundo lugar, há que se ressaltar que se o médico, enquanto preposto do nosocômio, não foi achado por culpa, então por extensão aquele estaria eximido de qualquer tipo de responsabilização, pois a questão que se põe em julgamento é a atuação do profissional. Por terceiro, a própria alegação de " infecção hospitalar" há que ser muito bem analisada, pois somos todos portadores de infindáveis tipos de bactérias que, muitas vezes, estão apenas esperando uma condição propícia, tal qual a queda de nossa resistência orgânica, para, então, entrar em ação com toda a sua virulência. ${ }^{98}$

\footnotetext{
${ }^{97}$ FERNANDES, Silvia da Cunha. As Técnicas de Reprodução Humana Assistida e a Necessidade de sua Regulamentação Jurídica. Rio de Janeiro: Renovar, 2005. p.138

${ }_{98}$ GIOSTRI, Hildegard Taggesell. ERRO MÉDICO à luz da Jurisprudência Comentada. 2. ed. Curitiba: Juruá Editora, 2007. p.279.
} 
Desta forma, duas situações devem ser observadas em se tratando de responsabilidade de Hospitais e Clínicas que realizam essas técnicas.

No caso de dano causado ao paciente por erro no atendimento devido a defeito em serviços exclusivamente prestados pelo hospital, o que norteará a responsabilização do hospital será a Teoria da Responsabilidade Objetiva ("art. 14, caput do Código de Defesa do Consumidor"), incumbindo ao hospital provar as excludentes de ilicitude do art. $14 \S 3^{\circ}$ do CDC como único modo de se exonerar do encargo.

Na ementa abaixo relacionada é possível perceber uma falha do hospital pelo não fornecimento do equipamento necessário.

Ementa:Responsabilidade civil de hospital por erro médico. Fibroplastia retrolental (cegueira) resultante de excessiva oxigenação do recém nascido prematuro. Falta de aparelhos medidores do oxigênio ministrado na unidade neonatal e ausência de relatórios médicos. Teoria da carga dinâmica da prova. A seqüela irreversível na visão do autor por ato culposo de preposto da ré determina o pagamento de indenização por perdas e danos materiais e morais. Pensão a estender-se por toda a vida da vítima, relativamente à redução da capacidade laborativa e adaptação do autor à vida sem o sentido perdido, relevando ainda o fato de se tratar de hospital de caridade. Havendo também ato próprio do nosocômio, pelo não fornecimento do equipamento necessário, os juros compostos incidem. ${ }^{99}$ ( grifos nossos)

No entanto, se o suposto dano for causado por atuação de um médico torna-se necessário verificar se o profissional médico agiu ou não com imperícia, imprudência ou negligência ("art. 14, § $4^{\circ}$ do Código de Defesa do Consumidor") para estender a responsabilidade para os hospitais e Clínicas.

Assim, na hipótese de verdadeiro erro essencial na utilização de uma técnica de inseminação artificial em que pais brancos têm filho negro ou de

${ }^{99}$ TJRS, Ap. Cível n ${ }^{\circ} 98450$ 401, Rel a ${ }^{\text {Des }}{ }^{\text {a }}$. Rejane Dias de Castro Bins, Rio Grande do Sul, 12.05.1999. 
graves anomalias no filho, a responsabilidade se estende à Clínica que prestou o serviço devido à imperícia do profissional.

Corroborando o exposto, destacamos o julgado do Tribunal de Justiça do Rio de Janeiro, que traz a responsabilidade objetiva do hospital devido a dano por falha de serviço exclusivo e no caso de erro de médico traz o requisito da culpa para estender a responsabilidade para os Hospitais.

RESPONSABILIDADE CIVIL. ERRO MÉDICO. FETO NATIMORTO. SOLIDARIEDADE DO HOSPITAL NA CULPA DO SEU PREPOSTO (ART. 14, $\S 4^{\circ}$, CDC). A doutrina tem se posicionado no sentido de que a responsabilidade médica empresarial, no caso de hospitais, é objetiva, indicando $0 \$ 1^{\circ}$ do artigo 14 do Código de Defesa do Consumidor. Contudo, deve-se ter em mente que tal responsabilidade somente tem lugar quando o dano decorrer de falha de serviços cuja atribuição é afeta única e exclusivamente ao hospital. Nas hipóteses de dano decorrente de falha técnica restrita ao profissional médico, incidirá a regra do $\S 4^{\circ}$, do art. 14 do CDC, impondo-se a solidariedade do hospital na culpa do seu preposto. Como bem salientado pelo Ministro Ruy Rosado de Aguiar, no IV Congresso Internacional sobre Danos, realizado em Buenos Aires "O hospital não responde objetivamente, mesmo depois da vigência do Código de Defesa do Consumidor, quando se trata de indenizar danos produzidos por médico integrante de seus quadros, pois é preciso provar a culpa deste para somente depois ter como presumida a culpa do hospital." No caso dos autos, o laudo médico pericial faz consignar que o fato da ausculta do batimento cardíaco fetal não ter sido realizada por pelo menos 2 (duas) vezes ao dia, quando havia evidências de que as contrações se mantinham, foi fator que impediu o diagnóstico precoce de sofrimento fetal e a intervenção cirúrgica a tempo e a hora de salvar a vida da criança. Negligência e imperícia caracterizadas. Dano moral que deve ser majorado para 150 (cento e cinqüenta) salários mínimos, tendo em vista tratar-se de morte de nascituro no final da gravidez, quando a expectativa da mãe pelo futuro nascimento já atingira o grau máximo, tomando mais elevada a dor pela perda. Nego seguimento ao recurso do réu (art. 557, caput, CPC) e dou parcial provimento ao recurso da autora (art. 557, § 1-A). ${ }^{100}$ (grifos nossos)

As clínicas, centros ou serviços que aplicam as referidas técnicas são responsáveis pelo controle de doenças infecto-contagiosas, coleta, manuseio, conservação, distribuição e transferência de material biológico humano para a usuária de técnicas de RA.

100 TJ, Ap. Cível no 2009.001.06923, Rel. DES. RENATA COTTA, Rio de Janeiro, 24/03/2009. 
No tocante aos bancos de gametas e embriões, estão eles vinculados por um contrato de depósito, aplicando-se as mesmas regras que foram mencionadas para as clínicas. ${ }^{101}$

Em relação aos serviços complementares, que consistem em serviços laboratoriais de análises clínicas (testes hormonais, espermogramas, etc.) e serviços especializados (raio X, ultra-sonografia); a obrigação é de resultado e os danos deverão ser reparados independente da prova de culpa cuja justificativa se assenta no risco da atividade. ${ }^{102}$

Ementa: Responsabilidade civil - Serviço defeituoso [erro de exame de laboratório] implica responsabilidade independente da prova da culpa [art. 14, da Lei 8078/90], devendo o prestador compensar as vítimas pelos constrangimentos e perturbações de falso resultado de esterilidade do varão, quando, em seguida, a mulher engravida - Provimento para julgar a ação procedente e condenar ao pagamento de $\mathrm{R} \$ 10.000,00$, por danos morais ${ }^{103}$

Vale mencionar a existência de demandas objetivando o tratamento para infertilidade no âmbito do SUS em hospitais públicos, devido à previsão da Portaria n ${ }^{\circ} 426$ de 2005 do Ministério da Saúde.

Ementa: APELAÇÃO CÍVEL - Mandado de Segurança - Prestação de serviço público e obrigação de fazer - Fornecimento de medicamentos para a realização de fertilização in vitro - Hipossuficiência para a aquisição Admissibilidade - A Constituição Brasileira e a Estadual garantem o amplo acesso e o atendimento integral à saúde da população, sem nenhuma restrição Inexistência de dispositivo legal que limite o fornecimento de medicamentos apenas aos cidadãos que estejam em iminente perigo de morte - A saúde deve ser interpretada em seu sentido amplo, englobando o aspecto físico e mental do ser humano - Recurso provido. ${ }^{104}$

${ }^{101}$ FERNANDES, Silvia da Cunha. As Técnicas de Reprodução Humana Assistida e a Necessidade de sua Regulamentação Jurídica. Rio de Janeiro: Renovar, 2005.p. 139.

${ }^{102}$ PÁDUA, Amélia do Rosário Motta de. Responsabilidade Civil na reprodução Assistida. Rio de Janeiro: Lumen Júris, 2008.p205

103 TJSP, Apelação n³326434500, Rel. Enio Zuliani, São Paulo, 13/09/2007

104 TJSP, Ap. Cível com revisão n ${ }^{\circ}$ 5785585500, Rel. Osvaldo José de Oliveira, São Paulo, $30 / 07 / 2008$ 


\subsection{A RESPONSABILIDADE CIVIL PERANTE OS DOADORES E RECEPTORES}

A doação de material fertilizante, sêmen, óvulos, e até mesmo embriões ainda não é regulamentada. No entanto, é possível fazermos analogia à doação de sangue ou de órgãos, que se encontram devidamente regulamentadas nas Leis 8.489/92 e decreto n 879 de 22 de junho de 1993, respectivamente. ${ }^{105}$

A doação de óvulos e sêmen envolve todo um procedimento de triagem de doadores, onde são realizados inúmeros exames, num processo de investigação meticuloso. ${ }^{106}$

Assim, por exemplo, se devido a erro laboratorial (imperícia, ou negligencia da pessoa que manipula o material), ocorrer mistura do esperma de dois doadores, não sendo mais possível identificar quem o doou, ou no caso de revelarem a identidade do doador, cabe a exigência de reparação pelos danos sofridos.

Outra hipótese em que caberá demanda judicial é quando o Banco de Sêmen não cumprir o processo investigatório dentro dos padrões de qualidade e segurança indicados, fornecendo sêmen de homem portador de doença infecto-contagiosa e causando danos na receptora e na criança. $\mathrm{O}$ laboratório além de arcar com os danos morais suportados pelos pais deve responder pelos danos materiais, a título de pagamento de valores investidos no procedimento de RA e das despesas necessárias com tratamentos da mulher e da criança. ${ }^{107}$

\footnotetext{
${ }^{105}$ FERNANDES, Silvia da Cunha. As Técnicas de Reprodução Humana Assistida e a Necessidade de sua Regulamentação Jurídica. Rio de Janeiro: Renovar, 2005

${ }^{106}$ PÁDUA, Amélia do Rosário Motta de. Responsabilidade Civil na reprodução Assistida. Rio de Janeiro: Lumen Júris, 2008.p.211

${ }^{107}$ PÁDUA, Amélia do Rosário Motta de. Responsabilidade Civil na reprodução Assistida. Rio de Janeiro: Lumen Júris, 2008.p
} 
Vale lembrar que a obrigação do médico é de meio, ele deve atuar com zelo e diligência nos procedimentos evitando os erros acima mencionados, mas não se obriga com o resultado final que é a gravidez.

Ementa: Embargos do Devedor - Título de Crédito - Cheques Serviços médicos na área de fertilização in vitro e transferência de gametas, zigotos ou pré-embriões e criopreservação - Atividade médica não idêntica à dos outros profissionais - Obrigação ê de meio e não de resultado - A vida e saúde humanas são ditadas por conceitos não exatos Sentença que julga improcedentes os embargos - Apelação desprovida. ${ }^{108}$

Além disso, a confidencialidade das informações a respeito dos doadores e receptores deve ser preservada, cabendo às clínicas ou bancos de sêmen a coleta e o arquivo dos dados de forma sigilosa, sob pena de responderem civil e penalmente pelos danos causados. ${ }^{109}$

E finalmente, haverá responsabilidade quando não forem observados os deveres de cuidado em relação à receptora de um tratamento de fertilização, conforme acórdão abaixo destacado.

RESPONSABILIDADE CIVIL DE MEDICO, ERRO MÉDICO, NEGLIGENCIA, PERDA DE ORGAO INTERNO, GRAVIDEZ INTERRUPCAO, EXAME MEDICO INOCORRENCIA, DANO MORAL, INDENIZACAO,ARBITRAMENTO,DESCONSTITUICAO DE NEGOCIO JURIDICO Responsabilidade Civil. Mulher que vinha fazendo tratamento para engravidar e que veio a suspendê-lo, por se constatar ser ela portadora de miamatose uterina. Histerectomia total, não precedida de exames específicos para verificação de possível gravidez. Sonegação, pelo cirurgião, do exame histopatológico, o qual revelou, além do mioma uterino, gravidez uterina com embrião vivo medindo 4,5 cm. Ação de Reparação de Dano. Provimento parcial. Agravo retido contra decisão que rejeitou contradita. Apelação. E' ineficaz a contradita apresentada depois que a testemunha depôs. Resultando do exame dos elementos constantes dos autos que não estava afastada a possibilidade de a autora vir a engravidar-se, a cirurgia a que ela se submeteu não poderia realizarse sem que a precedessem exames específicos. Respondem o medico e o hospital pelo dano causado, ante a manifesta negligencia daquele. A regra tradicional do nosso direito positivo, expressa no artigo 1.553 do Código Civil, e' a de que a

108 TSPS, Apelação n ${ }^{\circ}$ 209415200, Relator(a): Sulaiman Miguel Neto, São Paulo, Data do julgamento: 24/04/2006

${ }^{109}$ Art. 154 do Código Penal: Revelar a alguém, sem justa causa, segredo, de que têm ciência em razão de função, ministério, ofício ou profissão, e cuja revelação possa produzir dano a outrem: Pena- detenção, de 3(três) meses a 1(um) ano, ou multa. 
indenização, desde que seu valor não seja expressamente previsto para o caso especifico, devera' ser fixada por arbitramento judicial. Demais, com o advento da Constituição, tornou-se questionável a adoção de indenização tarifaria, entendendo-se que ela restringe o direito que a Carta Magna consagrou de ser indenizavel o dano moral (art. 5. V e X), de forma ampla e irrestrita. (CLG) ${ }^{110}($

A fim de minimizar os riscos de dano aos doadores e receptores dessas técnicas será necessário que as clínicas ou bancos de sêmen detenham o monopólio de coleta de material fertilizante, bem como seu preparo e manutenção, sob a direção de um médico geneticista.

\subsection{EXISTE RESPONSABILIDADE CIVIL POR DANOS AO EMBRIÃO IN VITRO?}

As indagações sobre bioética acirram-se diante da possibilidade de se formarem embriões excedentes no processo de reprodução assistida.

Hodiernamente são fertilizados em média, quinze óvulos, e destes são selecionados e implantados no útero apenas três ou quatro para evitar o engravidamento múltiplo. É necessário questionarmos qual destino terão os demais pré-embriões? Podem eles ser considerados como vida humana merecedores de proteção? ${ }^{111}$

A nossa legislação atual, não prevê o descarte de óvulos fertilizados (embriões) como ilícito penal. A resolução $\mathrm{n}^{\circ}$ 1.358/92, embora não seja clara em relação ao destino que deve ser dado aos embriões excedentes, proíbe o descarte de pré-embrião, podendo esta conduta ensejar processo e pena administrativa ao médico.

\footnotetext{
${ }^{110}$ TJ, Apelação Cível no 2000.001.13507, Relator. DES. CARLOS FERRARI, Rio de Janeiro, 13/02/2001.

${ }^{111}$ SEBASTIÃO, Jurandir. Responsabilidade Médica Civil, Criminal e Ética. Belo Horizonte: DelRey. 2003 p. 256
} 
Tal resolução exige definição prévia e assunção de responsabilidade por parte dos doadores para criopreservação (congelamento) e o destino do pré-embrião, com vistas tanto ao futuro desses mesmos doadores (morte, divórcio, doença grave) como ao futuro implante ou doação do préembrião.

No caso de doação para pesquisa científica, vale mencionar que a Assembléia Legislativa do Estado do Rio de Janeiro (Alerj) aprovou no mês de dezembro de 2008, projeto de lei $n^{\circ} 13 / 08$ que modificou a redação da Lei Complementar $\mathrm{n}^{\mathbf{o}} 102$, de 18 de março de 2003, tornando possível o financiamento de pesquisas com células-tronco embrionárias. Com a decisão, grupos de cientistas envolvidos em terapia celular animaram-se com a possibilidade de mais recurso para o desenvolvimento de seus trabalhos. $^{112}$

O pesquisador Stevens Rehen nos revela a dimensão dessas pesquisas:

"As células-tronco embrionárias, como o nome diz, são encontradas no embrião humano e têm capacidade de se transformar em praticamente qualquer célula do corpo. Como crescem rapidamente, transformam-se em células especializadas com características consistentes de vários tecidos, como músculos ou nervos, ossos ou sangue, sua potencial aplicação terapêutica em doenças cardiovasculares, crônico-degenerativas e no tratamento de pacientes vítimas de acidentes cerebrais, entre outras aplicações, tem despertado o interesse de cientistas em todo o mundo. As pesquisas têm como alvo o tratamento de doenças que afetam um grande numero de cidadãos, como a doença de Parkinson, o mal de Alzheimer, a diabetes mellitus, problemas cardíacos, doenças sanguíneas e câncer, dentre muitas outras."

Apesar dos tentadores argumentos expostos acima, cinco países europeus proibiram formalmente qualquer pesquisa em embriões.. $\mathrm{Na}$ Irlanda o embrião é considerado pessoa e protegido constitucionalmente.

\footnotetext{
112 HOMERO, Vilma. Rio avança em pesquisas com células-tronco. Revista Rio Pesquisa. Rio de Janeiro, n. 6, p.34-37, Ano II.

${ }^{113}$ Ibid.
} 
Na Noruega e Áustria qualquer pesquisa sobre embriões é inadmissível e na Dinamarca, alguns tipos de experiência são proibidos. ${ }^{114}$

Em relação à natureza jurídica dos embriões podemos destacar duas correntes divergentes. Há os que entendem que a vida humana tem início no momento do simples encontro do espermatozóide com o óvulo formando o pré-embrião, a partir do qual um novo ser humano se define geneticamente, com todas as expectativas da futura pessoa humana não sendo mais possível cogitar em descarte, sob pena de violência contra a vida.

Defende esta corrente Maria Helena Diniz que afirma: "ser devido o mais absoluto respeito pela vida e integridade física e mental dos embriões pré-implantados ou dos nascituros, sendo suscetível de indenização por dano moral qualquer lesão que venham a sofrer." 115

Vale mencionar algumas palavras de Fábio Ulhoa Coelho:

"para esta corrente não há nenhuma diferença essencial entre o embrião (mesmo fecundado in vitro) e um ser humano adulto, em termos de dignidade. A mesma proteção conferida pelo direito a este deve estender-se àquele, por conseguinte. A conclusão de tais argumentos é a de que os embriões in vitro são sujeitos de direito e merecem como os nascituros, tutela da lei." 116

No entanto, há os que em maioria entendem que não basta o simples encontro do espermatozóide com o óvulo, formando o pré-embrião (zigoto). Isto porque o processo de uma nova vida humana só se desenvolve quando houver a fixação desse óvulo fecundado na parede uterina (nidação).

É a partir da fixação no útero que o óvulo fecundado (pré-embrião) passa à condição de embrião, com todos os seus reflexos jurídicos de

${ }^{114}$ FERNANDES, Silvia da Cunha. As Técnicas de Reprodução Humana Assistida e a Necessidade de sua Regulamentação Jurídica. Rio de Janeiro: Renovar, 2005. p.

${ }_{115}$ DINIZ, Maria Helena. O Estado Atual do biodireito. $2^{\mathrm{a}}$ ed. São Paulo: Saraiva, 2002.p.115.

${ }^{116}$ Coelho. Fábio Ulhoa. Curso de Direito Civil vol 1. São Paulo: Saraiva, 2003. p.149. 
proteção e de igualdade como nascituro pelas expectativas de direitos que daí decorrem. Assim, o embrião in vitro não é sujeito de direito, mas bem da propriedade comum dos fornecedores de espermatozóide e óvulo. ${ }^{117}$

A doutrina reconhece a proteção de direitos apenas ao nascituro. O jurista José Carlos Barbosa Moreira, ao ventilar a matéria, expressou que "no ordenamento brasileiro, seja qual for a explicação dogmática, o nascituro, conquanto ainda não haja adquirido personalidade tem direitos; e estes não são apenas os indicados em disposições específicas". ${ }^{118}$

À mesma idéia filia-se Cáio Mário:

"a personalidade jurídica, no nosso direito, tem começo no nascimento com vida. Mas, a lei cuida, em dadas circunstâncias, de proteger e resguardar os interesses do nascituro, pois se reconhece a existência de um direito em potencial ao ente concebido.Como exemplo, a curatela do nascituro( artigo 1.779 e art. 1.780 do Código Civil), a admissibilidade de ser constituído herdeiro ou legatário o concebido (art.1.799 do Código Civil), de receber doação ( art. 542 do Código Civil) etc." 119

Com o objetivo de discutir e deliberar propostas de enunciados ao novo Código Civil, se reuniram no dia 02/12/2004, quatro comissões, formadas por 108 operadores do Direito. O entendimento da Comissão de Direito de Família e Sucessões, reunida no Conselho da Justiça Federal, é o de que embriões humanos não implantados devem ter proteção jurídica. ${ }^{120}$

De acordo com o professor da Universidade Federal do Paraná Luiz Edson Fachin, o enunciado aprovado não reconhece a prerrogativa de sujeito de direito aos embriões implantados, mas confere proteção jurídica equiparável ao nascituro.

\footnotetext{
${ }^{117}$ Ibid.

${ }^{118}$ MOREIRA, José Carlos Barbosa. O Direito do Nascituro. In. Revista Brasileira de Direito de Família. No 34. fev- mar 2006 P.143 a 152

${ }^{119}$ PEREIRA. Cáio Mário da Silva. Instituições de Direito Civil. Vol. 1. $21^{\mathrm{a}}$ edição. Ed Forense. 2005

${ }^{120}$ http://www.stj.gov.br/portal_stj/publicacao acesso em 10/05/2009
} 
"Foi dado um passo adiante no sentido de que não é possível considerar o embrião congelado como objeto ou coisa. Esses embriões têm o mesmo reconhecimento proporcionado aos nascituros, que não são considerados sujeitos de direito, pois não adquiriram personalidade pelo fato de ainda não terem nascido" $" 121$

Não obstante, os tribunais ainda não se manifestaram acerca da natureza jurídica do embrião in vitro, embora já enfrentem demandas postulando reparação pela morte destes em laboratório.

Ementa: cerceamento de defesa, inocorrência. ação de indenização por dano material e moral, alegada necessidade de produção de prova pericial. Hipótese contudo em que se mostra ela absolutamente desnecessária para o deslinde da causa. desnecessidade de dilação probatória agravo retido improvido. indenização. inocorrência de responsabilidade civil por dano material e moral pela morte de cinco pré-embriões. ausência de nexo de causalidade. Todavia entre o possível erro e o resultado manutenção em congelamento que não garante sobre-vida aos embriões obrigação que é de meio e não de resultado ausência de ilicitude do comportamento verba indevida. ação julgada improcedente recurso da ré provido, prejudicado o exame daquele dos autores. ${ }^{122}$ (grifos nossos)

Enquanto se discute a natureza jurídica do embrião in viro, torna-se difícil vislumbrar alguma hipótese de responsabilidade civil sobre eles. Além disso, seria inviável garantir a todos os pré-embriões o direito de ter um útero para se desenvolver.

Apenas quando o embrião fertilizado in vitro é implantado no útero tornando-se nascituro é que tem seus direitos resguardos. Esta vem sendo a orientação jurisprudencial no direito brasileiro

Ementa "Civil. Nascituro. Proteção de seu direito, na verdade proteção de expectativa, que se tornara direito, se ele nascer vivo. Venda feita pelos pais a irmã do nascituro. As hipóteses previstas no código civil, relativas a direitos do nascituro, são exaustivas, não os equiparando em tudo ao já nascido. ${ }^{123}$

\footnotetext{
121 Ibid.

${ }^{122}$ TJSP, apelação n³112144400, Rel. Vito Guglielmi, São Paulo, 26/03/2007

${ }^{123}$ STF, RE 99038/ MG, Francisco Rezek. Brasilia, 18/10/1983
} 
Desta forma, enquanto não for verificada a implantação in útero, o pré-embrião é objeto de direito, um bem, cujas especialidades a lei deve urgentemente tratar, podendo os genitores doar para outro casal ou para pesquisa após três anos de congelamento. Após a implantação in útero é que são resguardados direitos do nascituro que pode receber doação, alimentos gravídicos e inclusive indenização por danos.

Ementa: Erro médico. Danos causados ao nascituro. Seqüelas permanentes. Dever de indenizar do Estado. Pensão mensal e danos morais. Valores reduzidos. Recurso fazendário provido em parte. Retificação em reexame necessário. ${ }^{124}$

${ }^{124}$ TJRJ, Apelação no 2008.001.44341, Rel. DES. BERNARDO MOREIRA GARCEZ NETO, Rio de Janeiro, 29/10/2008. 


\section{CONCLUSÃO}

O direito vem auxiliando cada vez mais o lesado na procura de um responsável pela reparação integral do prejuízo, seja moral ou patrimonial. Com isso, é notório o crescente número de demandas decorrentes das técnicas de reprodução humana assistida, pois a sociedade não destina mais à vítima de um dano o papel de se conformar com o fatalismo.

Neste diapasão, torna-se imprescindível uma legislação específica que regulamente o uso destas técnicas e suas consequiências no mundo jurídico. Afinal, até o presente momento, existem apenas projetos de lei tramitando no Congresso, de modo que resta ao juiz proferir suas decisões com base em analogia, costumes, princípios constitucionais e da bioética, que o norteiam.

Ao analisarmos as condutas dos envolvidos nestes procedimentos, quais sejam, médicos, clínicas, doadores e receptores, bem como a questão do embrião in vitro que poderá ou não ser implantado no útero da mulher, chegamos às seguintes conclusões.

A responsabilidade civil do médico é de natureza contratual e envolve obrigação de meio, exceto em procedimentos de exames laboratoriais. Assim, o médico, ao atuar com técnicas de reprodução humana assistida, deve ter prudência e diligência necessárias, mas não se obriga com o resultado final, que é a gravidez. Somente se houver negligência, imprudência ou imperícia poderá o profissional ser responsabilizado por sua conduta.

Ao aplicar as referidas técnicas, dentre as diversas responsabilidades a que o médico está sujeito, podemos destacar: sigilo profissional, aviso quanto à possibilidade de falha técnica, consentimento do cliente, pesquisas 
de antecedente e causas de infertilidade, seleção rigorosa do doador e assepsia médica.

Entendemos que o contrato médico é de prestação de serviço. Isto porque, a relação médico-paciente passou a ser enxergada como de consumo, figurando o médico na posição de fornecedor e o paciente na de consumidor, podendo incidir as regras do Código de Defesa do Consumidor, inclusive a inversão do ônus da prova.

Em relação às clínicas que utilizam estas técnicas e aos bancos de material fertilizante devemos observar duas situações distintas. Se o dano resultou de falha no serviço prestado, como a falta de um aparelho, a responsabilidade será objetiva. No entanto, se o dano decorreu de um erro médico, é necessário provar a conduta culposa do mesmo para estender a responsabilidade às clínicas e bancos de material fertilizante.

Vale ressaltar que nos serviços complementares, que consistem em serviços laboratoriais de análises clínicas (testes hormonais, espermogramas, etc.) e serviços especializados (raio X, ultra-sonografia) a obrigação é de resultado, ou seja, existe vinculação com o resultado final.

No tocante aos doadores é necessário que as clínicas e médicos mantenham o sigilo das doações e tenham zelo evitando a mistura de sêmen de vários doadores. Quanto aos receptores, antes de receberem qualquer inseminação, os médicos devem fazer a triagem no sêmen doado evitando a contaminação de doenças infecto-contagiosas. Ocorrendo falhas nestes procedimentos, os usuários podem ensejar reparação cível.

A respeito dos embriões in vitro excedentes, entendemos ainda não ser possível falar em sujeitos de direitos, capazes de sofrer danos materiais ou morais. Apenas após a implantação in útero é que ficam resguardados os 
direitos do nascituro até o nascimento com vida, podendo inclusive sofrer danos indenizáveis.

O objetivo principal do presente trabalho foi abordar a responsabilidade civil dos envolvidos nas técnicas de reprodução humana assistida, mas o tema envolve outras questões relevantes. É possível que haja a colisão entre princípios constitucionais como o direito à intimidade do doador e o direito à identidade da criança; o direito ao planejamento familiar e a dignidade da pessoa humana. Apesar de ocorrer à ponderação de princípios no caso concreto, esses conflitos demonstram a real necessidade de normas que regulamentem estas questões.

Não cabe ao Direito impedir os avanços da medicina e desenvolvimento da biotecnologia, mas impor limites legais e assegurar direitos dos envolvidos no uso destas técnicas.

Está no cerne deste trabalho a percepção de que embora todos os envolvidos no uso destas técnicas venham a ser responsabilizados civil e penalmente, isto não pode interferir nos direitos daquele ser humano que irá nascer.

É importante destacar o princípio do melhor interesse da criança. Afinal, até que ponto o acordo entre os pais reflete o melhor interesse para a criança? A busca pela felicidade de cada um de nós não pode ser egoísta. $\mathrm{O}$ casal ao se deparar com o desejo de formar uma família possui formas alternativas de concretizar este sonho como a prática da adoção. Assim, crianças abandonadas também se beneficiariam e ambos criariam elos afetivos.

Desta forma, deve-se definir qual a real finalidade das pesquisas tecnológicas e qual o uso que delas se deve fazer. Qualquer reflexão 
jurídica ou bioética deste problema, somente terá sentido se servir para resgatar o homem do processo desumanizado de produção.

Espera-se que o presente trabalho tenha alcançado o objetivo proposto, que se despe da pretensão de encontrar soluções pacíficas para controvérsias presentes, mas que se propõe a contribuir para uma reflexão profunda e cautelosa sobre uma questão que reside na razão da existência do próprio homem, e vai além de procedimentos científicos.

Está na seiva desse estudo à lição do filósofo Immanuel Kant de que a vida e o ser humano não são meros instrumentos e sim um fim que se justifica, no plano ético, por si mesmo. 


\section{BIBLIOGRAFIA}

AMARAL, Francisco. A visão do Biodireito. In: Anais do Encontro Regional do Simpósio de Bioética e Biodireito. 1997

BARATA, Maria Eliza Mazolla. A responsabilidade civil do médico. Rio de Janeiro. 1981. 164p. Dissertação de Mestrado - Departamento de Ciências Jurídicas da PUC- Rio

BARBOZA, Heloisa Helena. Princípios do Biodireito. In. Novos temas de Biodireito e Bioética. Org. Heloisa Helena Barboza et al. Rio de Janeiro: Renovar, 2005.

BOLZAN, Alejandro D. Reprodução Humana Assistida e dignidade humana. São Paulo: Paulinas, 1998.

CARVALHO, Luiz Paulo Vieira. Direito Civil. 3. ed. Niterói/RJ: Impetus, 2009. 545p

COELHO, Fábio Ulhoa. Curso de Direito Civil vol. 1. São Paulo: Saraiva, 2003. 388 p.

CRUZ, Alex. A responsabilidade Civil do Médico. MÍDIA JURÍDICA MURAL Direito em Movimento. Rio de Janeiro, n.62, p.6-10, mar. 2009.

DA SILVA, José Afonso. Curso de Direito Constitucional Positivo. Malheiros Editores. 24a edição, 2005.

DE MORAIS, Alexandre. Direito Constitucional. $15^{\text {a }}$ ed. São Paulo: Atlas, 2004.

DIAS, Maria Berenice. Manual de Direito das Famílias. $4^{\text {a }}$ ed. São Paulo: Revista dos Tribunais, 2007. 608 p.

DINIZ, Debora; Guilhem, Dirce. O que é Bioética. São Paulo: editora brasiliense, 2002.

DINIZ, Maria Helena. O Estado Atual do biodireito. $2^{\mathrm{a}}$ ed. São Paulo: Saraiva, 2002. 840 p.

DINIZ. Maria Helena. Curso de Direito Civil Brasileiro vol. 7. 18 a ed. São Paulo: Saraiva, 2004. 648 p. 
FERNANDES, Silvia da Cunha. As Técnicas de Reprodução Humana Assistida e a Necessidade de sua Regulamentação Jurídica. Rio de Janeiro: Renovar, 2005. 334 p.

FILHO, Sergio Cavalieri. Programa de Responsabilidade Civil. $7^{\text {a }}$ ed. São Paulo: Atlas S.A., 2007. 561 p.

FISCILETTI, Rossana; CRUZ, Alex. Alimentos aos Nascituros. MÍDIA JURÍDICA MURAL Direito em Movimento. Rio de Janeiro, n. 63, p.6-9 abril/maio 2009.

GAMA, Guilherme Nogueira da. A nova Filiação: o biodireito e as relações parentais. Rio de Janeiro/São Paulo. 2003

GIOSTRI, Hildegard Taggesell. ERRO MÉDICO à luz da Jurisprudência Comentada. 2. ed. Curitiba: Juruá Editora, 2007.

LUZ, Newton Wiethorn; NETO, Francisco José Rodrigues de Oliveira. Ato Médico: Aspectos Éticos e legais. Rio de Janeiro: Rubio, 2002.

MARQUES, Claudia Lima. Contratos no Código de Defesa do Consumidor. O novo regime das relações contratuais. $5^{\text {a }}$ ed. São Paulo: Revista dos Tribunais, 2005. 1.342p.

MORAES, Maria Celina Bodin de. Danos à Pessoa Humana: uma leitura civil-constitucional dos danos morais. Rio de Janeiro: Renovar, 2003. 356p.

MOREIRA, José Carlos Barbosa. O Direito do Nascituro. In. Revista Brasileira de Direito de Família. No 34. fev-mar 2006 P.143 a 152

NADER, Paulo. Curso de Direito Civil. Vol. 7. Rio de Janeiro: Forense, 2008. $518 \mathrm{p}$.

PÁDUA, Amélia do Rosário Motta de. Responsabilidade Civil na reprodução Assistida. Rio de Janeiro: Lumen Júris, 2008. 293 p.

PEREIRA, Caio Mário da Silva. Instituições de Direito Civil. Vol. I. $21^{\text {a }}$ ed. Rio de Janeiro: Forense, 2005.718 p.

PEREIRA, Caio Mário da Silva.Instituições de Direito Civil. Vol. V. $16^{\mathrm{a}}$ Ed. Rio de Janeiro: Forense, 2006.

PEREIRA, Jane Reis Gonçalves. Interpretação Constitucional e Direitos Fundamentais. São Paulo: Renovar, 2006. 
PEREIRA, Tânia da Silva. O melhor interesse da criança: um debate interdisciplinar. Rio de Janeiro/São Paulo: Renovar, 2000.

PEREIRA. Cáio Mário da Silva. Instituições de Direito Civil vol. 1. 21 edição. Ed Forense. 2005.

PESSINI, Leo. Fundamentos da BIOÉTICA. São Paulo, $3^{\mathrm{a}}$ ed. São Paulo: Paulus, 2005. $89 \mathrm{p}$.

PESSINI, Leo. Problemas atuais de Bioética. $6^{a}$ ed. São Paulo:Loyola, 2002. $549 \mathrm{p}$.

ROCHA, Cleonice Rodrigues Casarin da. A responsabilidade Civil Decorrente do Contrato de Serviços Médicos. $1^{\mathrm{a}}$ ed. Rio de Janeiro: Forense, 2005.

RODRIGUES, Silvio. Direito Civil - Responsabilidade Civil vol. 4. São Paulo: Saraiva, 2003.

RODRIGUES. Silvio. Direito Civil Parte Geral. São Paulo: Saraiva. $34^{\mathrm{a}}$ edição, 2003.

SCHOPENHAUER, Arthur. Sobre a coisa em si e a aparência In: Strathern, Paul. Schopenhauer em 90 minutos.

SEBASTIÃO, Jurandir. Responsabilidade Médica Civil, Criminal e Ética. Belo Horizonte: DelRey, 2003. 450 p.

SILVA, de Plácido e. Vocabulário Jurídico. $23^{\mathrm{a}}$ ed. Rio de Janeiro: Forense, 2003.

TEPEDINO, Gustavo et al.. Código Civil Intrepretado: Conforme a Constituição da Republica. São Paulo: Renovar, 2004.

VENOSA, Sílvio de Salvo. Direito Civil. 5a edição. Vol.4. São Paulo. Editora Atlas. 2005.

\section{PÁGINAS DA INTERNET}

http://www.projetobeta.com.br/servicos.asp

http://www.tj.rj.gov.br

http://www.tj.sp.gov.br/

http://www.stj.gov.br 


\title{
ANEXO I
}

\section{MINISTÉRIO DA SAÚDE GABINETE DO MINISTRO}

\section{PORTARIA N 426, DE 22 DE MARÇO DE 2005}

\author{
Diário Oficial da União; Poder Executivo, Brasília, DF, n. 56, de 23 mar. 2005. Seção 1,
} p. $22-3$

Institui, no âmbito do SUS, a Política Nacional de Atenção Integral em Reprodução Humana Assistida e dá outras providências.

O MINISTRO DE ESTADO DA SAÚDE, no uso de suas atribuições, e

Considerando a necessidade de estruturar no Sistema Único de Saúde - SUS uma rede de serviços regionalizada e hierarquizada que permita atenção integral em reprodução humana assistida e melhoria do acesso a esse atendimento especializado;

Considerando que a assistência em planejamento familiar deve incluir a oferta de todos os métodos e técnicas para a concepção e a anticoncepção, cientificamente aceitos, de acordo com a Lei ${ }^{\circ} 9.263$, de 12 de janeiro de 1996, que regula o $\S 7^{\circ}$ do art. 226 da Constituição Federal, que trata do planejamento familiar;

Considerando que, segundo a Organização Mundial da Saúde - OMS e sociedades científicas, aproximadamente, $8 \%$ a $15 \%$ dos casais têm algum problema de infertilidade durante sua vida fértil, sendo que a infertilidade se define como a ausência de gravidez após 12 (doze) meses de relações sexuais regulares, sem uso de contracepção;

Considerando que as técnicas de reprodução humana assistida contribuem para a diminuição da transmissão vertical e/ou horizontal de doenças infecto-contagiosas, genéticas, entre outras;

Considerando a necessidade de estabelecer mecanismos de regulação, fiscalização, controle e avaliação da assistência prestada aos usuários; e

Considerando a necessidade de estabelecer os critérios mínimos para o credenciamento e a habilitação dos serviços de referência de Média e Alta Complexidade em reprodução humana assistida na rede SUS, resolve:

Art. $1^{\circ}$ Instituir, no âmbito do Sistema Único de Saúde - SUS, a Política Nacional de Atenção Integral em Reprodução Humana Assistida, a ser implantada em todas as unidades federadas, respeitadas as competências das três esferas de gestão.

Art. $2^{\circ}$ Determinar que a Política Nacional de Atenção Integral em Reprodução Humana Assistida seja implantada de forma articulada entre o Ministério da Saúde, as Secretarias de Estado de Saúde e as Secretarias Municipais de Saúde, permitindo:

I - organizar uma linha de cuidados integrais (promoção, prevenção, tratamento e reabilitação) que perpasse todos os níveis de atenção, promovendo, dessa forma, a atenção por intermédio de equipe multiprofissional, com atuação interdisciplinar;

II - identificar os determinantes e condicionantes dos principais problemas de infertilidade em casais em sua vida fértil, e desenvolver ações transetoriais de responsabilidade pública, sem excluir as responsabilidades de toda a sociedade; 
III - definir critérios técnicos mínimos para o funcionamento, o monitoramento e a avaliação dos serviços que realizam os procedimentos e técnicas de reprodução humana assistida, necessários à viabilização da concepção, tanto para casais com infertilidade, como para aqueles que se beneficiem desses recursos para o controle da transmissão vertical e/ou horizontal de doenças;

IV - fomentar, coordenar e executar projetos estratégicos que visem ao estudo do custoefetividade, eficácia e qualidade, bem como a incorporação tecnológica na área da reprodução humana assistida no Brasil;

V - promover intercâmbio com outros subsistemas de informações setoriais, implementando e aperfeiçoando permanentemente a produção de dados e garantindo a democratização das informações; e

VI - qualificar a assistência e promover a educação permanente dos profissionais de saúde envolvidos com a implantação e a implementação da Política de Atenção Integral em Reprodução Humana Assistida, em conformidade com os princípios da integralidade e da Política Nacional de Humanização - PNH.

Art. $3^{\circ}$ Definir que a Política Nacional de Atenção Integral em Reprodução Humana Assistida, de que trata o artigo $1^{\circ}$ desta Portaria, seja constituída a partir dos seguintes componentes fundamentais:

I - Atenção Básica: é a porta de entrada para a identificação do casal infértil e na qual devem ser realizados a anamnese, o exame clínico-ginecológico e um elenco de exames complementares de diagnósticos básicos, afastando-se patologias, fatores concomitantes e qualquer situação que interfira numa futura gestação e que ponham em risco a vida da mulher ou do feto;

II - Média Complexidade: os serviços de referência de Média Complexidade estarão habilitados a atender aos casos encaminhados pela Atenção Básica, realizando acompanhamento psicossocial e os demais procedimentos do elenco deste nível de atenção, e aos quais é facultativa e desejável, a realização de todos os procedimentos diagnósticos e terapêuticos relativos à reprodução humana assistida, à exceção dos relacionados à fertilização in vitro; e

III - Alta Complexidade: os serviços de referência de Alta Complexidade estarão habilitados a atender aos casos encaminhados pela Média Complexidade, estando capacitados para realizar todos os procedimentos de Média Complexidade, bem como a fertilização in vitro e a inseminação artificial.

$\S \mathbf{1}^{\mathbf{0}}$ A rede de atenção de Média e Alta Complexidade será composta por:

a) serviços de referência de Média e Alta Complexidade em reprodução humana assistida; e

b) serviços de Assistência Especializada - SAE que são de referência em DST/HIV/Aids.

$\S 2^{\circ}$ Os componentes descritos no caput deste artigo devem ser organizados segundo o Plano Diretor de Regionalização - PDR de cada unidade federada e segundo os princípios e diretrizes de universalidade, eqüidade, regionalização, hierarquização e integralidade da atenção à saúde.

Art. $4^{\circ}$ A regulamentação suplementar e complementar do disposto nesta Portaria ficará a cargo dos estados, do Distrito Federal e dos municípios, com o objetivo de regular a atenção em reprodução humana assistida.

$\$ 1^{\mathbf{0}}$ A regulação, a fiscalização, o controle e a avaliação das ações de atenção em reprodução humana assistida serão de competência das três esferas de governo.

$\S 2^{\mathbf{0}}$ Os componentes do caput deste artigo deverão ser regulados por protocolos de conduta, de referência e de contra-referência em todos os níveis de atenção que permitam o aprimoramento da atenção, da regulação, do controle e da avaliação. 
Art. $5^{\circ}$ A capacitação e a educação permanente das equipes de saúde de todos os âmbitos da atenção envolvendo os profissionais de nível superior e os de nível técnico, deverão ser realizadas de acordo com as diretrizes do SUS e alicerçadas nos pólos de educação permanente em saúde.

Art.6 $^{\circ}$ Determinar à Secretaria de Atenção à Saúde - SAS, isoladamente ou em conjunto com outras Secretarias do Ministério da Saúde, que adote todas as providências necessárias à plena estruturação da Política Nacional de Atenção Integral em Reprodução Humana Assistida, ora instituída.

Art. $7^{0}$ Esta Portaria entra em vigor na data de sua publicação.

\section{HUMBERTO COSTA}




\section{ANEXO II}

RESOLUÇÃO CFM No 1.358, DE 1992

O CONSELHO FEDERAL DE MEDICINA, no uso das atribuições que the confere a Lei $\mathrm{n}^{\mathrm{o}} 3.268$, de 30 de setembro de 1957, regulamentada pelo Decreto 44.045, de 19 de julho de 1958, e

CONSIDERANDO a importância da infertilidade humana como um problema de saúde, com implicações médicas e psicológicas, e a legitimidade do anseio de superá-la;

CONSIDERANDO que o avanço do conhecimento científico já permite solucionar vários dos casos de infertilidade humana;

CONSIDERANDO que as técnicas de Reprodução Assistida têm possibilitado a procriação em diversas circunstâncias em que isto não era possível pelos procedimentos tradicionais;

CONSIDERANDO a necessidade de harmonizar o uso destas técnicas com os princípios da ética médica;

CONSIDERANDO, finalmente, o que ficou decidido na Sessão Plenária do Conselho Federal de Medicina realizada em 11 de novembro de 1992;

\section{RESOLVE}

Art. $1^{\circ}$ - Adotar as NORMAS ÉTICAS PARA A UTILIZAÇÃO DAS TÉCNICAS DE REPRODUÇÃO ASSISTIDA, anexas à presente Resolução, como dispositivo deontológico a ser seguido pelos médicos.

Art. $2^{\circ}$ - Esta Resolução entra em vigor na data da sua publicação.

\section{NORMAS ÉTICAS PARA A UTILIZAÇÃO DAS TÉCNICAS DE REPRODUÇÃO ASSISTIDA}

\section{I - PRINCÍPIOS GERAIS}

1 - As técnicas de Reprodução Assistida (RA) têm o papel de auxiliar na resolução dos problemas de infertilidade humana, facilitando o processo de procriação quando outras terapêuticas tenham sido ineficazes ou ineficientes para a solução da situação atual de infertilidade. 
2 - As técnicas de RA podem ser utilizadas desde que exista probabilidade efetiva de sucesso e não se incorra em risco grave de saúde para a paciente ou o possível descendente.

3 - O consentimento informado será obrigatório e extensivo aos pacientes inférteis e doadores. Os aspectos médicos envolvendo todas as circunstâncias da aplicação de uma técnica de RA serão detalhadamente expostos, assim como os resultados já obtidos naquela unidade de tratamento com a técnica proposta. As informações devem também atingir dados de caráter biológico, jurídico, ético e econômico. $\mathrm{O}$ documento de consentimento informado será em formulário especial, e estará completo com a concordância, por escrito, da paciente ou do casal infértil.

4 - As técnicas de RA não devem ser aplicadas com a intenção de selecionar o sexo ou qualquer outra característica biológica do futuro filho, exceto quando se trate de evitar doenças ligadas ao sexo do filho que venha a nascer.

5 - É proibido a fecundação de oócitos humanos, com qualquer outra finalidade que não seja a procriação humana.

6 - O número ideal de oócitos e pré-embriões a serem transferidos para a receptora não deve ser superior a quatro, com o intuito de não aumentar os riscos já existentes de multiparidade.

7 - Em caso de gravidez múltipla, decorrente do uso de técnicas de RA, é proibida a utilização de procedimentos que visem a redução embrionária.

\section{II - USUÁRIOS DAS TÉCNICAS DE RA}

1 - Toda mulher, capaz nos termos da lei, que tenha solicitado e cuja indicação não se afaste dos limites desta Resolução, pode ser receptora das técnicas de RA, desde que tenha concordado de maneira livre e consciente em documento de consentimento informado.

2 - Estando casada ou em união estável, será necessária a aprovação do cônjuge ou do companheiro, após processo semelhante de consentimento informado.

\section{III - REFERENTE ÀS CLÍNICAS, CENTROS OU SERVIÇOS QUE APLICAM TÉCNICAS DE RA}

As clínicas, centros ou serviços que aplicam técnicas de RA são responsáveis pelo controle de doenças infecto-contagiosas, coleta, manuseio, conservação, distribuição e transferência de material biológico humano para a usuária de técnicas de RA, devendo apresentar como requisitos mínimos: 
1 - um responsável por todos os procedimentos médicos e laboratoriais executados, que será, obrigatoriamente, um médico.

2 - um registro permanente (obtido através de informações observadas ou relatadas por fonte competente) das gestações, nascimentos e mal-formações de fetos ou recémnascidos, provenientes das diferentes técnicas de RA aplicadas na unidade em apreço, bem como dos procedimentos laboratoriais na manipulação de gametas e pré-embriões.

3 - um registro permanente das provas diagnósticas a que é submetido o material biológico humano que será transferido aos usuários das técnicas de RA, com a finalidade precípua de evitar a transmissão de doenças.

\section{IV - DOAÇÃO DE GAMETAS OU PRÉ-EMBRIÕES}

1 - A doação nunca terá caráter lucrativa ou comercial.

2 - Os doadores não devem conhecer a identidade dos receptores e vice-versa.

3 - Obrigatoriamente será mantido o sigilo sobre a identidade dos doadores de gametas e pré-embriões, assim como dos receptores. Em situações especiais, as informações sobre doadores, por motivação médica, podem ser fornecidas exclusivamente para médicos, resguardando-se a identidade civil do doador.

4 - As clínicas, centros ou serviços que empregam a doação devem manter, de forma permanente, um registro de dados clínicos de caráter geral, características fenotípicas e uma amostra de material celular dos doadores.

5 - Na região de localização da unidade, o registro das gestações evitará que um doador tenha produzido mais que 2 (duas) gestações, de sexos diferentes, numa área de um milhão de habitantes.

6 - A escolha dos doadores é de responsabilidade da unidade. Dentro do possível deverá garantir que o doador tenha a maior semelhança fenotípica e imunológica e a máxima possibilidade de compatibilidade com a receptora.

7 - Não será permitido ao médico responsável pelas clínicas, unidades ou serviços, nem aos integrantes da equipe multidisciplinar que nelas prestam serviços, participarem como doadores nos programas de RA.

\section{V - CRIOPRESERVAÇÃO DE GAMETAS OU PRÉ-EMBRIÕES}

1 - As clínicas, centros ou serviços podem criopreservar espermatozóides, óvulos e préembriões. 
2 - O número total de pré-embriões produzidos em laboratório será comunicado aos pacientes, para que se decida quantos pré-embriões serão transferidos a fresco, devendo o excedente ser criopreservado, não podendo ser descartado ou destruído.

3 - No momento da criopreservação, os cônjuges ou companheiros devem expressar sua vontade, por escrito, quanto ao destino que será dado aos pré-embriões criopreservados, em caso de divórcio, doenças graves ou de falecimento de um deles ou de ambos, e quando desejam doá-los.

\section{VI - DIAGNÓSTICO E TRATAMENTO DE PRÉ-EMBRIÕES}

As técnicas de RA também podem ser utilizadas na preservação e tratamento de doenças genéticas ou hereditárias, quando perfeitamente indicadas e com suficientes garantias de diagnóstico e terapêutica.

1 - Toda intervenção sobre pré-embriões "in vitro", com fins diagnósticos, não poderá ter outra finalidade que a avaliação de sua viabilidade ou detecção de doenças hereditárias, sendo obrigatório o consentimento informado do casal.

2 - Toda intervenção com fins terapêuticos, sobre pré-embriões "in vitro", não terá outra finalidade que tratar uma doença ou impedir sua transmissão, com garantias reais de sucesso, sendo obrigatório o consentimento informado do casal.

3 - O tempo máximo de desenvolvimento de pré-embriões "in vitro" será de 14 dias.

\section{VII - SOBRE A GESTAÇÃO DE SUBSTITUIÇÃO (DOAÇÃO TEMPORÁRIA DO ÚTERO)}

As Clínicas, Centros ou Serviços de Reprodução Humana podem usar técnicas de RA para criarem a situação identificada como gestação de substituição, desde que exista um problema médico que impeça ou contra-indique a gestação na doadora genética.

1 - As doadoras temporárias do útero devem pertencer à família da doadora genética, num parentesco até o segundo grau, sendo os demais casos sujeitos à autorização do Conselho Regional de Medicina.

2 - A doação temporária do útero não poderá ter caráter lucrativo ou comerciaL. 


\section{ANEXO III}

PROJETO DE LEI No 90, DE 1999

Dispõe sobre a Procriação Medicamente Assistida

O CONGRESSO NACIONAL decreta:

\section{SEÇÃO I DOS PRINCÍPIOS GERAIS}

Artigo $1^{\circ}$ Esta Lei disciplina o uso das técnicas de Procriação Medicamente Assistida (PMA) que importam na implantação artificial de gametas ou embriões humanos, fertilizados in vitro, no aparelho reprodutor de mulheres receptoras.

Parágrafo único. Para os efeitos desta Lei, atribui-se a denominação de:

I - beneficiários aos cônjuges ou ao homem e à mulher em união estável, conforme definido na Lei $\mathrm{n}^{\circ}$ 8.971, de 29 de dezembro de 1994, que tenham solicitado o emprego de Procriação Medicamente Assistida;

II - gestação de substituição ao caso em que uma mulher, denominada genitora substituta, tenha autorizado sua inseminação artificial ou a introdução, em seu aparelho reprodutor, de embriões fertilizados in vitro, com o objetivo de gerar uma criança para os beneficiários, observadas as limitações do art. $3^{\circ}$ desta Lei;

III - consentimento livre e esclarecido ao ato pelo qual os beneficiários são esclarecidos sobre a Procriação Medicamente Assistida e manifestam consentimento para a sua realização.

Artigo $2^{\circ}$ A utilização da Procriação Medicamente Assistida só será permitida, na forma autorizada nesta Lei e em seus regulamentos, nos casos em que se verifica infertilidade e para a prevenção de doenças genéticas ligadas ao sexo, e desde que:

I - exista, sob pena de responsabilidade, conforme estabelecido no art. 38 desta Lei, indicação médica para o emprego da Procriação Medicamente Assistida, consideradas as demais possibilidades terapêuticas disponíveis, e não se incorra em risco grave de saúde para a mulher receptora ou para a criança;

II - a receptora da técnica seja uma mulher civilmente capaz, nos termos da lei, que tenha solicitado o tratamento de maneira livre e consciente, em documento a ser elaborado conforme o disposto nos arts. $4^{\circ}$ e $5^{\circ}$ desta Lei; 
III - a receptora da técnica seja apta, física e psicologicamente, após avaliação que leve em conta sua idade cronológica e outros critérios estabelecidos em regulamento.

$\S 1^{\circ}$ Somente os cônjuges ou o homem e a mulher em união estável poderão ser beneficiários das técnicas de Procriação Medicamente Assistida.

$\S 2^{\circ}$ Caso não se diagnostique causa definida para a situação de infertilidade, observar-seá, antes da utilização da Procriação Medicamente Assistida, prazo mínimo de espera, que será estabelecido em regulamento e levará em conta a idade da mulher receptora.

Artigo $3^{\circ}$ Fica permitida a gestação de substituição em sua modalidade não-remunerada, nos casos em que exista um problema médico que impeça ou contra-indique a gestação na beneficiária e desde que haja parentesco até o segundo grau entre os beneficiários e a genitora substituta.

Parágrafo único. A gestação de substituição não poderá ter caráter lucrativo ou comercial, ficando vedada a modalidade conhecida como útero ou barriga de aluguel.

\section{SEÇÃO II \\ DO CONSENTIMENTO LIVRE E ESCLARECIDO}

Artigo $4^{\circ} \mathrm{O}$ consentimento livre e esclarecido será obrigatório para ambos os beneficiários, vedada a manifestação da vontade por procurador, e será formalizado por instrumento particular, que conterá necessariamente os seguintes esclarecimentos: I - a indicação médica para o emprego de Procriação Medicamente Assistida, no caso específico;

II - os aspectos técnicos e as implicações médicas das diferentes fases das modalidades de Procriação Medicamente Assistida disponíveis, bem como os custos envolvidos em cada uma delas;

III - os dados estatísticos sobre a efetividade das técnicas de Procriação Medicamente Assistida nas diferentes situações, incluídos aqueles específicos do estabelecimento e do profissional envolvido, comparados com os números relativos aos casos em que não se recorreu à Procriação Medicamente Assistida;

IV - a possibilidade e a probabilidade de incidência de danos ou efeitos indesejados para as mulheres e para os nascituros;

V - as implicações jurídicas da utilização da Procriação Medicamente Assistida;

VI - todas as informações concernentes à capacitação dos profissionais e estabelecimentos envolvidos;

VII - demais informações estabelecidas em regulamento. 
$\S 1^{\circ} \mathrm{O}$ consentimento mencionado neste artigo, a ser efetivado conforme as normas regulamentadoras que irão especificar as informações mínimas a serem transmitidas, será exigido do doador e de seu cônjuge, ou da pessoa com quem viva em união estável. $\S 2^{\circ}$ No caso do parágrafo anterior, as informações mencionadas devem incluir todas as implicações decorrentes do ato de doar, inclusive a possibilidade de a identificação do doador vir a ser conhecida.

Artigo $5^{\circ} \mathrm{O}$ consentimento deverá refletir a livre manifestação da vontade dos envolvidos, e o documento originado deverá explicitar:

I - a técnica e os procedimentos autorizados pelos beneficiários, inclusive o número de embriões a serem produzidos, observado o limite disposto no art. 14 desta Lei;

II - as circunstâncias em que doador ou depositante autoriza ou desautoriza a utilização de seus gametas.

\section{SEÇÃO III \\ DOS ESTABELECIMENTOS E PROFISSIONAIS QUE REALIZAM A PROCRIAÇÃO MEDICAMENTE ASSISTIDA}

Art. $6^{\circ}$ Clínicas, centros, serviços e demais estabelecimentos que realizam a Procriação Medicamente Assistida são responsáveis:

I - pela elaboração, em cada caso, de laudo com a indicação da necessidade e oportunidade para a realização da técnica de Procriação Medicamente Assistida; II - pelo recebimento de doações e pelas fases de coleta, manuseio, controle de doenças infecto-contagiosas, conservação, distribuição e transferência do material biológico humano utilizado na Procriação Medicamente Assistida, vedando-se a transferência a fresco de material doado;

III - pelo registro de todas as informações relativas aos doadores desse material e aos casos em que foi utilizada a Procriação Medicamente Assistida, pelo prazo de cinqüenta anos após o emprego das técnicas em cada situação;

IV - pela obtenção do consentimento livre e esclarecido dos beneficiários de Procriação Medicamente Assistida, doadores e respectivos cônjuges ou companheiros em união estável, na forma definida na Seção II desta Lei;

$\mathrm{V}$ - pelos procedimentos médicos e laboratoriais executados.

Parágrafo único. As responsabilidades estabelecidas neste artigo não excluem outras, de caráter complementar, a serem estabelecidas em regulamento.

Art. $7^{\circ}$ Para obter a licença de funcionamento, clínicas, centros, serviços e demais estabelecimentos que aplicam Procriação Medicamente Assistida devem cumprir os seguintes requisitos mínimos: 
I - funcionar sob a direção de um profissional médico;

II - dispor de recursos humanos, técnicos e materiais condizentes com as necessidades científicas para realizar a Procriação Medicamente Assistida;

III - dispor de registro de todos os casos em que tenha sido empregada a Procriação Medicamente Assistida, ocorra ou não gravidez, pelo prazo de cinqüenta anos; IV - dispor de registro dos doadores e das provas diagnósticas realizadas no material biológico a ser utilizado na Procriação Medicamente Assistida com a finalidade de evitar a transmissão de doenças e manter esse registro pelo prazo de cinqüenta anos após o emprego do material;

V - informar o órgão competente, a cada ano, sobre suas atividades concernentes à Procriação Medicamente Assistida.

$\S 1^{\circ}$ A licença mencionada no caput deste artigo, obrigatória para todos os estabelecimentos que pratiquem a Procriação Medicamente Assistida, será válida por no máximo três anos e renovável ao término de cada período, podendo ser revogada em virtude do descumprimento de qualquer disposição desta Lei ou de seu regulamento. $2^{\circ}$ Exigir-se-á do profissional mencionado no inciso I deste artigo e dos demais médicos que atuam no estabelecimento prova de capacitação para o emprego de Procriação Medicamente Assistida.

$\S 3^{\circ} \mathrm{O}$ registro citado no inciso III deste artigo deverá conter, por meio de prontuários, elaborados inclusive para a criança, e de formulários específicos, a identificação dos beneficiários e doadores, as técnicas utilizadas, a pré-seleção sexual, quando imprescindível, na forma do art. 17 desta Lei, a ocorrência ou não de gravidez, o desenvolvimento das gestações, os nascimentos, as malformações de fetos ou recémnascidos e outros dados definidos em regulamento.

$\S 4^{\circ}$ Em relação aos doadores, o registro citado no inciso IV deste artigo deverá conter a identidade civil, os dados clínicos de caráter geral, foto acompanhada das características fenotípicas e amostra de material celular.

$\S 5^{\circ}$ As informações de que trata este artigo são consideradas sigilosas, salvo nos casos especificados nesta Lei.

$\S 6^{\circ}$ No caso de encerramento das atividades, os estabelecimentos de que trata esta Seção deverão transferir os registros mencionados nos incisos III e IV deste artigo para o órgão competente do Poder Público.

\author{
SEÇÃO IV \\ DAS DOAÇÕES
}


Art. $8^{\circ}$ Será permitida a doação de gametas, sob a responsabilidade dos estabelecimentos que praticam a Procriação Medicamente Assistida, vedadas a remuneração e a cobrança por esse material, a qualquer título.

$\S 1^{\circ}$ Não será permitida a doação quando houver risco de dano para a saúde do doador, levando-se em consideração suas condições físicas e mentais.

$\S 2^{\circ} \mathrm{O}$ doador de gameta é obrigado a declarar:

I - para quais estabelecimentos já realizou doação;

II - as doenças de que tem conhecimento ser portador.

$\S 3^{\circ}$ A regulamentação desta Lei poderá estabelecer idade limite para os doadores, com base em critérios que busquem garantir a qualidade dos gametas doados.

Art. $9^{\circ}$ Os estabelecimentos que praticam a Procriação Medicamente Assistida estarão obrigados a zelar pelo sigilo da doação e das informações sobre a criança nascida a partir de material doado.

Art. 10 Excepciona-se o sigilo estabelecido no artigo anterior nos casos autorizados nesta Lei, obrigando-se o estabelecimento responsável pelo emprego da Procriação Medicamente Assistida a fornecer as informações solicitadas.

$\S 1^{\circ}$ Quando razões médicas indicarem ser de interesse da criança obter informações genéticas necessárias para sua vida ou saúde, as informações relativas ao doador deverão ser fornecidas exclusivamente para o médico solicitante.

$\S 2^{\circ}$ No caso autorizado no parágrafo anterior, resguardar-se-á a identidade civil do doador, mesmo que o médico venha a entrevistá-lo para obter maiores informações sobre sua saúde.

Art. 11 A escolha dos doadores será responsabilidade do estabelecimento que pratica a Procriação Medicamente Assistida e deverá garantir, tanto quanto possível, semelhança fenotípica e compatibilidade imunológica entre doador e receptor.

Art. 12 Haverá um registro central de doações e gestações, organizado pelo Poder Público com base nas informações periodicamente fornecidas pelos estabelecimentos que praticam Procriação Medicamente Assistida, o qual será obrigatoriamente consultado para garantir que um mesmo doador só origine descendentes para um único par de beneficiários.

Art. 13 Não poderão ser doadores, exceto na qualidade de beneficiários, os dirigentes, funcionários e membros, ou seus parentes até o quarto grau, de equipe de qualquer estabelecimento que pratique a Procriação Medicamente Assistida e os civilmente incapazes.

SEÇÃO V

DOS GAMETAS E EMBRIÕES 
Art. 14 Na execução de técnica de Procriação Medicamente Assistida, poderão ser produzidos e transferidos até três embriões, respeitada a vontade da mulher receptora, a cada ciclo reprodutivo.

$\S 1^{\circ}$ Serão obrigatoriamente transferidos a fresco todos os embriões obtidos, obedecido o critério definido no caput deste artigo.

$\S 2^{\circ}$ Não se aplicam aos embriões originados in vitro, antes de sua introdução no aparelho reprodutor da mulher receptora, os direitos assegurados ao nascituro na forma da lei.

Art. 15 Os estabelecimentos que praticam a Procriação Medicamente Assistida ficam autorizados a preservar gametas humanos, doados ou depositados apenas para

armazenamento, pelos métodos permitidos em regulamento.

$\S 1^{\circ}$ Os gametas depositados apenas para armazenamento só poderão ser entregues à pessoa depositante, não podendo ser destruídos sem sua autorização.

$\S 2^{\circ}$ É obrigatório o descarte de gametas:

I - sempre que for solicitado pelo doador ou depositante;

II - sempre que estiver determinado no documento de consentimento livre e esclarecido;

III - nos casos conhecidos de falecimento de doador ou depositante, ressalvada a hipótese em que este último tenha autorizado, em testamento, a utilização póstuma de seus gametas pela esposa ou companheira.

Art. 16 Serão definidos em regulamento os tempos máximos de:

I - preservação de gametas depositados apenas para armazenamento;

II - desenvolvimento de embriões in vitro.

Art. 17 A pré-seleção sexual só poderá ocorrer nos casos em que os beneficiários recorram à Procriação Medicamente Assistida em virtude de apresentarem probabilidade genética para gerar crianças portadoras de doenças ligadas ao sexo, mediante autorização do Poder Público.

\section{SEÇÃO VI \\ DA FILIAÇÃO}

Art. 18 Será atribuída aos beneficiários a condição de pais da criança nascida mediante o emprego das técnicas de Procriação Medicamente Assistida.

Parágrafo único. É assegurado ao doador e à criança de que trata este artigo o direito recíproco de acesso, extensivo a parentes, a qualquer tempo, por meio do depositário dos registros concernentes à procriação, observado o disposto no inciso III do art. $6^{\circ}$, para o fim de consulta sobre disponibilidade de transplante de órgãos ou tecidos, garantido o anonimato. 
Art. 19 O doador e a genitora substituta, e seus parentes biológicos, não terão qualquer espécie de direito ou vínculo, quanto à paternidade ou maternidade, em relação à pessoa nascida a partir do emprego das técnicas de Procriação Medicamente Assistida, salvo os impedimentos matrimoniais.

Art. 20 As conseqüências jurídicas do uso da Procriação Medicamente Assistida, quanto à filiação, são irrevogáveis a partir do momento em que houver embriões originados in vitro ou for constatada gravidez decorrente de inseminação artificial.

Art. 21 A morte dos beneficiários não restabelece o pátrio poder dos pais biológicos Art. 22 O Ministério Público fiscalizará a atuação dos estabelecimentos que empregam técnicas de Procriação Medicamente Assistida, com o objetivo de resguardar os direitos do nascituro e a saúde e integridade física das pessoas, aplicando-se, no que couber, as disposições do Capítulo V da Lei no 8.069, de 13 de julho de 1990.

\section{SEÇÃO VII \\ DOS CRIMES}

Art. 23 Praticar a redução embrionária:

Pena - reclusão de um a quatro anos.

Parágrafo único. Não se pune a redução embrionária feita por médico se não houver outro meio de salvar a vida da gestante.

Art. 24 Praticar a Procriação Medicamente Assistida sem estar previamente capacitado para a atividade:

Pena - detenção, de um a três anos, e multa.

Art. 25 Praticar a Procriação Medicamente Assistida sem obter o consentimento livre e esclarecido dos beneficiários e dos doadores na forma determinada nesta Lei, bem como fazê-lo em desacordo com os termos constantes do documento de consentimento assinado por eles

Pena - reclusão, de dois a quatro anos, e multa.

Art. 26 Participar da prática de útero ou barriga de aluguel, na condição de beneficiário, intermediário ou executor da técnica:

Pena - reclusão, de um a três anos, e multa.

Art. 27 Fornecer gametas depositados apenas para armazenamento a qualquer pessoa que não seja o próprio depositante, bem como empregar esses gametas sem a autorização deste:

Pena - reclusão, de um a três anos, e multa. 
Art. 28 Deixar de manter as informações exigidas na forma especificada, deixar de fornecê-las nas situações previstas ou divulgá-las a outrem nos casos não autorizados, consoante as determinações desta Lei:

Pena - detenção, de um a três anos, e multa

Art. 29 Utilizar gametas de doadores ou depositantes sabidamente falecidos, salvo na hipótese em que o depositante tenha autorizado, em testamento, a utilização póstuma de seus gametas pela esposa ou companheira:

Pena - reclusão, de um a três anos, e multa

Art. 30 Implantar mais de três embriões na mulher receptora:

Pena - reclusão, de dois a seis anos, e multa

Art. 31 Realizar a pré-seleção sexual de gametas ou embriões, ressalvado o disposto nesta Lei:

Pena - reclusão, de um a três anos, e multa.

Art. 32 Participar da prática de útero ou barriga de aluguel, na condição de genitora substituta:

Pena - detenção, de seis meses a dois anos, ou multa.

Art. 33 Produzir embriões além da quantidade permitida:

Pena - reclusão de três a seis anos, e multa.

Art. 34 Armazenar, destruir, ou ceder embriões, ressalvados os casos previstos nesta Lei: Pena - reclusão de três a seis anos, e multa.

Art. 35 Deixar de implantar na mulher receptora os embriões produzidos, exceto no caso de contra-indicação médica:

Pena - detenção de dois a seis anos, e multa

Art. 36 Utilizar gameta:

I - doado por dirigente, funcionário ou membro de equipe de qualquer estabelecimento que pratique a Procriação Medicamente Assistida ou seus parentes até o quarto grau, e pelo civilmente incapaz;

II - de que tem ciência ser de um mesmo doador para mais de um par de beneficiários;

III - a fresco ou sem que tenha sido submetido ao controle de doenças infecto-

contagiosas:

Pena - reclusão de três a seis anos, e multa.

Parágrafo único. Na mesma pena incorre:

I - o médico que usar o seu próprio gameta para realizar a Procriação Medicamente

Assistida, exceto na qualidade de beneficiário;

II - o doador que omitir dados ou fornecer informação falsa ou incorreta sobre qualquer aspecto relacionado ao ato de doar. 
Art. 37 Realizar a procriação medicamente assistida em pessoas que não sejam casadas ou não vivam em união estável:

Pena - detenção, de seis meses a dois anos, ou multa.

Parágrafo único. Na mesma pena incorre o homem ou a mulher que solicitar o emprego da técnica para dela usufruir individualmente ou com outrem que não o cônjuge ou a companheira ou o companheiro.

Art. 38 A prática de qualquer uma das condutas arroladas nesta seção acarretará a perda da licença do estabelecimento de procriação medicamente assistida, sem prejuízo das demais sanções legais cabíveis.

Art. 39 O estabelecimento e os profissionais médicos que nele atuam são, entre si, civil e penalmente responsáveis pelo emprego da Procriação Medicamente Assistida.

\section{SEÇÃO VIII \\ DAS DISPOSIÇÕES FINAIS}

Art. 40 O Poder Público regulamentará esta Lei, inclusive quanto às normas especificadoras dos requisitos para a execução de cada técnica de Procriação

Medicamente Assistida, competindo-lhe também conceder a licença aos estabelecimentos que praticam a Procriação Medicamente Assistida e fiscalizar suas atuações.

Art. 41 Os embriões congelados existentes até a entrada em vigor da presente Lei poderão ser utilizados, com o consentimento das pessoas que os originaram, na forma permitida nesta Lei.

$\S 1^{\circ}$ Presume-se autorizada a utilização, para reprodução, de embriões originados in vitro existentes antes da entrada em vigor desta Lei, se, no prazo de sessenta dias a contar da data da publicação desta Lei, os depositantes não se manifestarem em contrário.

$\S 2^{\circ}$ Incorre na pena prevista no crime tipificado no art. 34 aquele que descartar embrião congelado anteriormente à entrada em vigor desta Lei.

Art. 42 A União poderá celebrar convênio com os Estados, com o Distrito Federal e com os Municípios para exercer, em conjunto ou isoladamente, a fiscalização dos estabelecimentos que praticam a Procriação Medicamente Assistida.

Art. 43 Esta Lei entrará em vigor no prazo de um ano a contar da data de sua publicação. 


\section{ANEXO IV}

PROJETO DE LEI Nº 1184, DE 2003

Dispõe sobre a Reprodução Assistida.

O CONGRESSO NACIONAL decreta:

\section{CAPÍTULO I DOS PRINCÍPIOS GERAIS}

Art $1^{\circ}$ Esta Lei regulamenta o uso das técnicas de Reprodução Assistida (RA) para a implantação artificial de gametas ou embriões humanos, fertilizados in vitro, no organismo de mulheres receptoras.

Parágrafo Único. Para os efeitos desta Lei, atribui-se a denominação de:

I - embriões humanos: ao resultado da união in vitro de gametas, previamente à sua implantação no organismo receptor, qualquer que seja o estágio de seu desenvolvimento; II - beneficiários: às mulheres ou aos casais que tenham solicitado o emprego da Reprodução Assistida;

III - consentimento livre e esclarecido: ao ato pelo qual os beneficiários são esclarecidos sobre a Reprodução Assistida e manifestam, em documento, consentimento para a sua realização, conforme disposto no Capítulo II desta Lei.

Art $2^{\circ} \mathrm{A}$ utilização das técnicas de Reprodução Assistida será permitida, na forma autorizada nesta Lei e em seus regulamentos, nos casos em que se verifique infertilidade e para a prevenção de doenças genéticas ligadas ao sexo, e desde que:

I - exista indicação médica para o emprego da Reprodução Assistida, consideradas as demais possibilidades terapêuticas disponíveis, segundo o disposto em regulamento; II - a receptora da técnica seja uma mulher civilmente capaz, nos termos da lei, que tenha solicitado o tratamento de maneira livre, consciente e informada, em documento de consentimento livre e esclarecido, a ser elaborado conforme o disposto no Capítulo II desta Lei;

III - a receptora da técnica seja apta, física e psicologicamente, após avaliação que leve em conta sua idade e outros critérios estabelecidos em regulamento;

IV - o doador seja considerado apto física e mentalmente, por meio de exames clínicos e complementares que se façam necessários.

Parágrafo único Caso não se diagnostique causa definida para a situação de infertilidade, observar-se-á, antes da utilização da Reprodução Assistida, prazo mínimo de espera, que será estabelecido em regulamento e levará em conta a idade da mulher receptora. 
Art $3^{\circ}$ É proibida a gestação de substituição.

\section{CAPÍTULO II DO CONSENTIMENTO LIVRE E ESCLARECIDO}

Art. $4^{\circ} \mathrm{O}$ consentimento livre e esclarecido será obrigatório para ambos os beneficiários, nos casos em que a beneficiária seja uma mulher casada ou em união estável, vedada a manifestação da vontade por procurador, e será formalizado em instrumento particular, que conterá necessariamente os seguintes esclarecimentos:

I - a indicação médica para o emprego de Reprodução Assistida, no caso específico, com manifestação expressa dos beneficiários da falta de interesse na adoção de criança ou adolescente;

II - os aspectos técnicos, as implicações médicas das diferentes fases das modalidades de Reprodução Assistida disponíveis e os custos envolvidos em cada uma delas;

III - os dados estatísticos referentes à efetividade dos resultados obtidos no serviço de saúde onde se realizará o procedimento de Reprodução Assistida;

IV - os resultados estatísticos e probabilísticos acerca da incidência e prevalência dos efeitos indesejados nas técnicas de Reprodução Assistida, em geral e no serviço de saúde onde esta será realizada;

V - as implicações jurídicas da utilização de Reprodução Assistida;

VI - os procedimentos autorizados pelos beneficiários, inclusive o número de embriões a serem produzidos, observado o limite disposto no art. 13 desta Lei;

VII - as condições em que o doador ou depositante autoriza a utilização de seus gametas, inclusive postumamente;

VIII - demais requisitos estabelecidos em regulamento.

$\S 1^{\circ} \mathrm{O}$ consentimento mencionado neste artigo será também exigido do doador e de seu cônjuge ou da pessoa com quem viva em união estável e será firmado conforme as normas regulamentadoras, as quais especificarão as informações mínimas que lhes serão transmitidas.

$\S 2^{\circ}$ No caso do $\S 1^{\circ}$, as informações mencionadas devem incluir todas as implicações decorrentes do ato de doar, inclusive a possibilidade de a identificação do doador vir a ser conhecida.

\section{CAPÍTULO III}

\section{DOS SERVIÇOS DE SAÚDE E PROFISSIONAIS}

Art. $5^{\circ}$ Os serviços de saúde que realizam a Reprodução Assistida são responsáveis: 
I - pela elaboração, em cada caso, de laudo com a indicação da necessidade e oportunidade para o emprego da técnica de Reprodução Assistida;

II - pelo recebimento de doações e pelas fases de coleta, manuseio, controle de doenças infecto-contagiosas, conservação, distribuição e transferência do material biológico humano utilizado na Reprodução Assistida, vedando-se a transferência de sêmen doado a fresco;

III - pelo registro de todas as informações relativas aos doadores e aos casos em que foi utilizada a Reprodução Assistida, pelo prazo de 50 (cinqüenta) anos;

IV - pela obtenção do consentimento livre e esclarecido dos beneficiários de Reprodução Assistida, doadores e respectivos cônjuges ou companheiros em união estável, na forma definida no Capítulo II desta Lei;

$\mathrm{V}$ - pelos procedimentos médicos e laboratoriais executados;

VI - pela obtenção do Certificado de Qualidade em Biossegurança junto ao órgão competente;

VII - pela obtenção de licença de funcionamento a ser expedida pelo órgão competente da administração, definido em regulamento.

Parágrafo único. As responsabilidades estabelecidas neste artigo não excluem outras, de caráter complementar, a serem estabelecidas em regulamento.

Art. $6^{\circ}$ Para obter a licença de funcionamento, os serviços de saúde que realizam Reprodução Assistida devem cumprir os seguintes requisitos mínimos:

I - funcionar sob a direção de um profissional médico, devidamente capacitado para realizar a Reprodução Assistida, que se responsabilizará por todos os procedimentos médicos e laboratoriais executados;

II - dispor de equipes multiprofissionais, recursos técnicos e materiais compatíveis com o nível de complexidade exigido pelo processo de Reprodução Assistida;

III - dispor de registro de todos os casos em que tenha sido empregada a Reprodução Assistida, ocorra ou não gravidez, pelo prazo de 50 (cinqüenta) anos; IV - dispor de registro dos doadores e das provas diagnósticas realizadas, pelo prazo de 50 (cinqüenta) anos após o emprego do material biológico; $\mathrm{V}$ - encaminhar relatório semestral de suas atividades ao órgão competente definido em regulamento.

$\S 1^{\circ}$ A licença mencionada no caput deste artigo será válida por até 3 (três) anos, renovável ao término de cada período, desde que obtido ou mantido o Certificado de Qualidade em Biossegurança, podendo ser revogada em virtude do descumprimento de qualquer disposição desta Lei ou de seu regulamento.

$\S 2^{\circ} \mathrm{O}$ registro citado no inciso III deste artigo deverá conter a identificação dos beneficiários e doadores, as técnicas utilizadas, a pré-seleção sexual, quando 
imprescindível, na forma do art. 15 desta Lei, a ocorrência ou não de gravidez, o desenvolvimento das gestações, os nascimentos, as malformações de fetos ou recémnascidos e outros dados definidos em regulamento.

$\S 3^{\circ}$ Em relação aos doadores, o registro citado no inciso IV deste artigo deverá conter a identidade civil, os dados clínicos de caráter geral, foto acompanhada das características fenotípicas e uma amostra de material celular.

$\S 4^{\circ}$ As informações de que trata este artigo são consideradas sigilosas, salvo nos casos especificados nesta Lei.

$\S 5^{\circ}$ No caso de encerramento das atividades, os serviços de saúde transferirão os registros para o órgão competente do Poder Público, determinado no regulamento.

\section{CAPÍTULO IV DAS DOAÇÕES}

Art. $7^{\circ}$ Será permitida a doação de gametas, sob a responsabilidade dos serviços de saúde que praticam a Reprodução Assistida, vedadas a remuneração e a cobrança por esse material, a qualquer título.

$\S 1^{\circ}$ Não será permitida a doação quando houver risco de dano para a saúde do doador, levando-se em consideração suas condições físicas e mentais.

$\S 2^{\circ} \mathrm{O}$ doador de gameta é obrigado a declarar:

I - não haver doado gameta anteriormente;

II - as doenças de que tem conhecimento ser portador, inclusive os antecedentes familiares, no que diz respeito a doenças genético-hereditárias e outras.

$\S 3^{\circ}$ Poderá ser estabelecida idade limite para os doadores, com base em critérios que busquem garantir a qualidade dos gametas doados, quando da regulamentação desta Lei. $\S 4^{\circ}$ Os gametas doados e não-utilizados serão mantidos congelados até que se dê o êxito da gestação, após o quê proceder-se-á ao descarte dos mesmos, de forma a garantir que o doador beneficiará apenas uma única receptora.

Art. $8^{\circ}$ Os serviços de saúde que praticam a Reprodução Assistida estarão obrigados a zelar pelo sigilo da doação, impedindo que doadores e beneficiários venham a conhecer reciprocamente suas identidades, e pelo sigilo absoluto das informações sobre a pessoa nascida por processo de Reprodução Assistida.

Art. $9^{\circ} \mathrm{O}$ sigilo estabelecido no art. $8^{\circ}$ poderá ser quebrado nos casos autorizados nesta Lei, obrigando-se o serviço de saúde responsável pelo emprego da Reprodução Assistida a fornecer as informações solicitadas, mantido o segredo profissional e, quando possível, o anonimato. 
$\S 1^{\circ}$ A pessoa nascida por processo de Reprodução Assistida terá acesso, a qualquer tempo, diretamente ou por meio de representante legal, e desde que manifeste sua vontade, livre, consciente e esclarecida, a todas as informações sobre o processo que o gerou, inclusive à identidade civil do doador, obrigando-se o serviço de saúde responsável a fornecer as informações solicitadas, mantidos os segredos profissional e de justiça.

$\S 2^{\circ}$ Quando razões médicas ou jurídicas indicarem ser necessário, para a vida ou a saúde da pessoa gerada por processo de Reprodução Assistida, ou para oposição de impedimento do casamento, obter informações genéticas relativas ao doador, essas deverão ser fornecidas ao médico solicitante, que guardará o devido segredo profissional, ou ao oficial do registro civil ou a quem presidir a celebração do casamento, que notificará os nubentes e procederá na forma da legislação civil.

$\S 3^{\circ}$ No caso de motivação médica, autorizado no $\S 2^{\circ}$, resguardar-se-á a identidade civil do doador mesmo que o médico venha a entrevistá-lo para obter maiores informações sobre sua saúde.

Art. 10 A escolha dos doadores será de responsabilidade do serviço de saúde que pratica a Reprodução Assistida e deverá assegurar a compatibilidade imunológica entre doador e receptor.

Art. 11 Não poderão ser doadores os dirigentes, funcionários e membros de equipes, ou seus parentes até o quarto grau, de serviço de saúde no qual se realize a Reprodução Assistida.

Parágrafo único. As pessoas absolutamente incapazes não poderão ser doadoras de gametas.

Art. 12 O Titular do Cartório de Registro Civil de Pessoas Naturais fica obrigado a comunicar ao órgão competente previsto no art. $5^{\circ}$, incisos VI e VII, até o dia 10 de cada mês, o registro dos óbitos ocorridos no mês imediatamente anterior, devendo da relação constar a filiação, a data e o local de nascimento da pessoa falecida.

$\S 1^{\circ}$ No caso de não haver sido registrado nenhum óbito, deverá o Titular do Cartório de Registro Civil de Pessoas Naturais comunicar esse fato ao referido órgão no prazo estipulado no caput deste artigo.

$\S 2^{\circ} \mathrm{A}$ falta de comunicação na época própria, bem como o envio de informações inexatas, sujeitará o Titular de Cartório de Registro Civil de Pessoas Naturais a multa variável de $\mathrm{R} \$ 636,17$ (seiscentos e trinta e seis reais e dezessete centavos) a $\mathrm{R} \$$ 63.617,35 (sessenta e três mil, seiscentos e dezessete reais e trinta e cinco centavos), na forma do regulamento.

$\S 3^{\circ}$ A comunicação deverá ser feita por meio de formulários para cadastramento de óbito, conforme modelo aprovado em regulamento. 
$\S 4^{\circ}$ Deverão constar, além dos dados referentes à identificação do Cartório de Registro Civil de Pessoas Naturais, pelo menos uma das seguintes informações relativas à pessoa falecida:

I - número de inscrição do PIS/Pasep;

II - número de inscrição do Instituto Nacional do Seguro Social - INSS, se contribuinte individual, ou número de benefício previdenciário - NB, se a pessoa falecida for titular de qualquer benefício pago pelo INSS;

III - número do CPF;

IV - número de registro de Carteira de Identidade e respectivo órgão emissor;

$\mathrm{V}$ - número do título de eleitor;

VI - número do registro de nascimento ou casamento, com informação do livro, da folha e do termo;

VII - número e série da Carteira de Trabalho.

\section{CAPÍTULO V DOS GAMETAS E EMBRIÕES}

Art. $13 \mathrm{Na}$ execução da técnica de Reprodução Assistida, poderão ser produzidos e transferidos até 2 (dois) embriões, respeitada a vontade da mulher receptora, a cada ciclo reprodutivo.

$\S 1^{\circ}$ Serão obrigatoriamente transferidos a fresco todos os embriões obtidos, obedecido ao critério definido no caput deste artigo.

$\S 2^{\circ}$ Os embriões originados in vitro, anteriormente à sua implantação no organismo da receptora, não são dotados de personalidade civil.

$\S 3^{\circ}$ Os beneficiários são juridicamente responsáveis pela tutela do embrião e seu ulterior desenvolvimento no organismo receptor.

$\S 4^{\circ}$ São facultadas a pesquisa e experimentação com embriões transferidos e espontaneamente abortados, desde que haja autorização expressa dos beneficiários.

$\S 5^{\circ} \mathrm{O}$ tempo máximo de desenvolvimento de embriões in vitro será definido em regulamento.

Art. 14 Os serviços de saúde são autorizados a preservar gametas humanos, doados ou depositados apenas para armazenamento, pelos métodos e prazos definidos em regulamento.

$\S 1^{\circ}$ Os gametas depositados apenas para armazenamento serão entregues somente à pessoa depositante, não podendo ser destruídos sem sua autorização.

$\S 2^{\circ}$ É obrigatório o descarte de gametas:

I - quando solicitado pelo depositante; 
II - quando houver previsão no documento de consentimento livre e esclarecido;

III - nos casos de falecimento do depositante, salvo se houver manifestação de sua vontade, expressa em documento de consentimento livre e esclarecido ou em testamento, permitindo a utilização póstuma de seus gametas.

Art. 15 A pré-seleção sexual será permitida nas situações clínicas que apresentarem risco genético de doenças relacionadas ao sexo, conforme se dispuser em regulamento.

\section{CAPÍTULO VI DA FILIAÇÃO DA CRIANÇA}

Art. 16 Será atribuída aos beneficiários a condição de paternidade plena da criança nascida mediante o emprego de técnica de Reprodução Assistida.

$\S 1^{\circ} \mathrm{A}$ morte dos beneficiários não restabelece o poder parental dos pais biológicos. $\S 2^{\circ}$ A pessoa nascida por processo de Reprodução Assistida e o doador terão acesso aos registros do serviço de saúde, a qualquer tempo, para obter informações para transplante de órgãos ou tecidos, garantido o segredo profissional e, sempre que possível, o anonimato.

$\S 3^{\circ} \mathrm{O}$ acesso mencionado no $\S 2^{\circ}$ estender-se-á até os parentes de $2^{\circ}$ grau do doador e da pessoa nascida por processo de Reprodução Assistida.

Art. $17 \mathrm{O}$ doador e seus parentes biológicos não terão qualquer espécie de direito ou vínculo, quanto à paternidade ou maternidade, em relação à pessoa nascida a partir do emprego das técnicas de Reprodução Assistida, salvo os impedimentos matrimoniais elencados na legislação civil.

Art. 18 Os serviços de saúde que realizam a Reprodução Assistida sujeitam-se, sem prejuízo das competências de órgão da administração definido em regulamento, à fiscalização do Ministério Público, com o objetivo de resguardar a saúde e a integridade física das pessoas envolvidas, aplicando-se, no que couber, as disposições da Lei $\mathrm{n}^{\circ}$ 8.069, de 13 de julho de 1990 (Estatuto da Criança e do Adolescente).

\section{CAPÍTULO VII DAS INFRAÇÕES E PENALIDADES}

Art. 19 Constituem crimes:

I - praticar a Reprodução Assistida sem estar habilitado para a atividade: Pena - detenção, de 1 (um) a 3 (três) anos, e multa; 
II - praticar a Reprodução Assistida sem obter o consentimento livre e esclarecido dos beneficiários e dos doadores na forma determinada nesta Lei ou em desacordo com os termos constantes do documento de consentimento por eles assinado:

Pena - reclusão, de 1 (um) a 4 (quatro) anos, e multa;

III - participar do procedimento de gestação de substituição, na condição de beneficiário, intermediário ou executor da técnica:

Pena - reclusão, de 1 (um) a 3 (três) anos, e multa;

IV - fornecer gametas depositados apenas para armazenamento a qualquer pessoa que não o próprio depositante, ou empregar esses gametas sem sua prévia autorização:

Pena - reclusão, de 1 (um) a 3 (três) anos, e multa;

$\mathrm{V}$ - deixar de manter as informações exigidas na forma especificada, não as fornecer nas situações previstas ou divulgá-las a outrem nos casos não autorizados, consoante as determinações desta Lei:

Pena - detenção, de 1 (um) a 3 (três) anos, e multa;

VI - utilizar gametas de doadores ou depositantes sabidamente falecidos, salvo na hipótese em que tenha sido autorizada, em documento de consentimento livre e esclarecido, ou em testamento, a utilização póstuma de seus gametas:

Pena - reclusão, de 1 (um) a 3 (três) anos, e multa;

VII - implantar mais de 2 (dois) embriões na mulher receptora:

Pena - reclusão, de 1 (um) a 3 (três) anos, e multa;

VIII - realizar a pré-seleção sexual de gametas ou embriões, ressalvado o disposto nesta Lei:

Pena - reclusão, de 1 (um) a 3 (três) anos, e multa;

IX - produzir embriões além da quantidade permitida:

Pena - reclusão, de 1 (um) a 3 (três) anos, e multa;

$\mathrm{X}$ - armazenar ou ceder embriões, ressalvados os casos em que a implantação seja contraindicada:

Pena - reclusão, de 1 (um) a 3 (três) anos, e multa;

XI - deixar o médico de implantar na mulher receptora os embriões produzidos, exceto no caso de contra-indicação médica:

Pena - reclusão, de 1 (um) a 3 (três) anos, e multa;

XII - descartar embrião antes da implantação no organismo receptor:

Pena - reclusão, de 1 (um) a 3 (três) anos, e multa;

XIII - utilizar gameta:

a) doado por dirigente, funcionário ou membro de equipe do serviço de saúde em que se realize a Reprodução Assistida, ou seus parentes até o quarto grau;

b) de pessoa incapaz; 
c) de que tem ciência ser de um mesmo doador, para mais de um beneficiário;

d) sem que tenham sido os beneficiários ou doadores submetidos ao controle de doenças infecto-contagiosas e a outros exames complementares:

Pena - reclusão, de 1 (um) a 3 (três) anos, e multa.

Parágrafo único. Ao aplicar as medidas previstas neste artigo, o juiz considerará a natureza e a gravidade do delito e a periculosidade do agente.

Art. 20 Constituem crimes:

I - intervir sobre gametas ou embriões in vitro com finalidade diferente das permitidas nesta Lei:

Pena - detenção, de 6 (seis) meses a 2 (dois) anos, e multa;

II - utilizar o médico do próprio gameta para realizar a Reprodução Assistida, exceto na qualidade de beneficiário:

Pena - detenção, de 1 (um) a 2 (dois) anos, e multa;

III - omitir o doador dados ou fornecimento de informação falsa ou incorreta sobre qualquer aspecto relacionado ao ato de doar:

Pena - detenção, de 1 (um) a 3 (três) anos, e multa;

IV - praticar o médico redução embrionária, com consentimento, após a implantação no organismo da receptora, salvo nos casos em que houver risco de vida para a mulher:

Pena - reclusão de 1 (um) a 4 (quatro) anos;

V - praticar o médico redução embrionária, sem consentimento, após a implantação no organismo da receptora, salvo nos casos em que houver risco de vida para a mulher:

Pena - reclusão de 3 (três) a 10 (dez) anos.

Parágrafo único. As penas cominadas nos incisos IV e V deste artigo são aumentadas de 1/3 (um terço), se, em conseqüência do procedimento redutor, a receptora sofre lesão corporal de natureza grave; e são duplicadas, se, pela mesma causa, lhe sobrevém a morte.

Art. 21 A prática de qualquer uma das condutas arroladas neste Capítulo acarretará a perda da licença do estabelecimento de Reprodução Assistida, sem prejuízo das demais sanções legais cabíveis.

\section{CAPÍTULO VIII}

\section{DAS DISPOSIÇÕES FINAIS}

Art. 22 Os embriões conservados até a data de entrada em vigor desta Lei poderão ser doados exclusivamente para fins reprodutivos, com o consentimento prévio dos primeiros beneficiários, respeitados os dispositivos do Capítulo IV. 
Parágrafo único. Presume-se autorizada a doação se, no prazo de 60 (sessenta) dias, os primeiros beneficiários não se manifestarem em contrário.

Art. 23 O Poder Público promoverá campanhas de incentivo à utilização, por pessoas inférteis ou não, dos embriões preservados e armazenados até a data de publicação desta Lei, preferencialmente ao seu descarte.

Art. 24 O Poder Público organizará um cadastro nacional de informações sobre a prática da Reprodução Assistida em todo o território, com a finalidade de organizar estatísticas e tornar disponíveis os dados sobre o quantitativo dos procedimentos realizados, a incidência e prevalência dos efeitos indesejados e demais complicações, os serviços de saúde e os profissionais que a realizam e demais informações consideradas apropriadas, segundo se dispuser em regulamento.

Art. 25 A Lei ${ }^{\circ}$ 8.974, de 5 de janeiro de 1995, passa a vigorar acrescida do seguinte art. $8^{\circ}-\mathrm{A}$ :

"Art. $8^{\circ}$-A. São vedados, na atividade com humanos, os experimentos de clonagem radical através de qualquer técnica de genetecnologia."

$\mathrm{O}$ art. 13 da Lei $\mathrm{n}^{\circ}$ 8.974, de 1995, passa a vigorar acrescido do seguinte inciso IV, renumerando-se os demais:

"Art. 13.

IV - realizar experimentos de clonagem humana radical através de qualquer técnica de genetecnologia;

..$(\mathrm{NR})$

Art. 27 Esta Lei entra em vigor 180 (cento e oitenta) dias a partir da data de sua publicação. 

